OPEN ACCESS

Karine Rizzoti,

Francis Crick Institute,

United Kingdom

Reviewed by:

David Hazlerigg,

The University of Tromsø-The Arctic

University of Norway, Norway

Paula Gabriela Vissio,

University of Buenos Aires, Argentina

${ }^{*}$ Correspondence:

Karine Rousseau

karine.rousseau@mnhn.fr

Sylvie Dufour

sylvie.dufour@mnhn.fr

${ }^{\dagger}$ Present address:

Mitchell Stewart Fleming,

Department of Biological Sciences

(BIO), University of Bergen,

Bergen, Norway

Gersende Maugars,

Faculty of Veterinary Medicine,

Norwegian University of Life Sciences,

Oslo, Norway

Specialty section:

This article was submitted to Neuroendocrine Science,

a section of the journal

Frontiers in Endocrinology

Received: 07 September 2020

Accepted: 15 October 2020

Published: 27 November 2020

Citation:

Fleming MS, Maugars G, Martin P,

Dufour S and Rousseau K (2020)

Differential Regulation of the

Expression of the Two Thyrotropin

Beta Subunit Paralogs by Salmon

Pituitary Cells In Vitro.

Front. Endocrinol. 11:603538.

doi: 10.3389/fendo.2020.603538

\section{Differential Regulation of the Expression of the Two Thyrotropin Beta Subunit Paralogs by Salmon Pituitary Cells In Vitro}

\author{
Mitchell Stewart Fleming ${ }^{1,2 \dagger}$, Gersende Maugars ${ }^{1 \dagger}$, Patrick Martin ${ }^{2}$, Sylvie Dufour ${ }^{1 *}$ \\ and Karine Rousseau ${ }^{1 *}$ \\ ${ }^{1}$ Muséum National d'Histoire Naturelle, Research Unit BOREA, Biology of Aquatic Organisms and Ecosystems, CNRS, IRD, \\ SU, UCN, UA, Paris, France, ${ }^{2}$ Conservatoire National du Saumon Sauvage (CNSS), Chanteuges, France
}

We recently characterized two paralogs of the thyrotropin (TSH) beta subunit in Atlantic salmon, tsh $\beta a$ and $t s h \beta b$, issued from teleost-specific whole genome duplication. The transcript expression of $t s h \beta b$, but not of tsh $\beta$ a, peaks at the time of smoltification, which revealed a specific involvement of tsh $\beta b$ paralog in this metamorphic event. Tsh $\beta a$ and tsh $\beta b$ are expressed by distinct pituitary cells in salmon, likely related to TSH cells from the pars distalis and pars tuberalis, respectively, in mammals and birds. The present study aimed at investigating the neuroendocrine and endocrine factors potentially involved in the differential regulation of $t s h \beta a$ and tsh $\beta b$ paralogs, using primary cultures of Atlantic salmon pituitary cells. The effects of various neurohormones and endocrine factors potentially involved in the control of development, growth, and metabolism were tested. Transcript levels of tsh $\beta$ a and tsh $\beta b$ were measured by qPCR, as well as those of growth hormone $(g h)$, for comparison and validation. Corticotropin-releasing hormone $(\mathrm{CRH})$ stimulated tsh $\beta$ a transcript levels in agreement with its potential role in the thyrotropic axis in teleosts, but had no effect on $t s h \beta b$ paralog, while it also stimulated gh transcript levels. Thyrotropin-releasing hormone (TRH) had no effect on neither tsh $\beta$ paralogs nor $g h$. Somatostatin $(\mathrm{SRIH})$ had no effects on both $\operatorname{tsh} \beta$ paralogs, while it exerted a canonical inhibitory effect on gh transcript levels. Thyroid hormones [triiodothyronine (T3) and thyroxine (T4)] inhibited transcript levels of both $t s h \beta$ paralogs, as well as $g h$, but with a much stronger effect on $t \operatorname{sh} \beta a$ than on $t s h \beta b$ and gh. Conversely, cortisol had a stronger inhibitory effect on $t s h \beta b$ than $t s h \beta a$, while no effect on $g h$. Remarkably, insulin-like growth factor 1 (IGF1) dose-dependently stimulated tsh $\beta b$ transcript levels, while it had no effect on tsh $\beta a$, and a classical inhibitory effect on gh. This study provides the first data on the neuroendocrine factors involved in the differential regulation of the expression of the two tsh $\beta$ paralogs. It suggests that IGF1 may be involved in triggering the expression peak of the tsh $\beta b$ paralog at smoltification, thus representing a potential internal signal in the link between body growth and smoltification metamorphosis.

Keywords: tsh $\beta$ paralogs, gh, thyroid hormones, cortisol, IGF1, CRH, Salmo salar, pituitary cells in vitro 


\section{HIGHLIGHTS}

- Atlantic salmon $t \operatorname{sh} \beta a$ and $t \operatorname{sh} \beta b$ paralog transcripts are differentially regulated by neuroendocrine factors in vitro

- Thyroid hormones have a stronger inhibitory effect on $t s h \beta a$ than on $t s h \beta b$ expression

- CRH specifically stimulates $t \operatorname{sh} \beta a$ but not $t \operatorname{sh} \beta b$ expression, while TRH and SRIH have no effect on both paralogs

- IGF1 specifically stimulates $t \operatorname{sh} \beta b$ but not $t \operatorname{sh} \beta a$ expression

- IGF1 may represent an internal cue linking growth and smoltification

\section{INTRODUCTION}

The thyrotropic axis is the major neuroendocrine axis involved in the control of development and metabolism in all vertebrates. It also triggers larval metamorphosis, as investigated in depth in anuran amphibians [for review: (1)], and also shown in some teleosts such as flatfishes [for review: (2)]. Together with other neuroendocrine axes, it may be involved in the control of other life history transitions, such as smoltification (parr-smolt transformation) in salmonids. Smoltification is a crucial late developmental event, which triggers the downstream migration to the sea of the juvenile salmon and preadapts it to seawater conditions, where it will complete its oceanic growth phase before returning to its natal river to spawn [for reviews: (3-5)]. Smoltification is referred to as "secondary metamorphosis" by some authors, by comparison to the "primary" or "true" larval metamorphosis [for reviews: (6-8)].

Classically, in mammals, the thyrotropic axis comprises a cerebral neuropeptide named thyrotropin-releasing hormone (TRH), which acts on the pituitary to induce the synthesis and release of thyrotropin (thyroid-stimulating hormone; TSH). This pituitary hormone stimulates the production by the thyroid gland of thyroid hormones, thyroxine (T4) and triiodothyronine (T3), which act on a variety of peripheral target organs. The thyroid hormones also exert negative feedbacks on the brain and pituitary to regulate TSH production [for reviews: $(9,10)]$. In nonmammalian vertebrates (amphibians and birds), some variations are observed in the thyrotropic axis, notably concerning the central control of TSH, which can also involve corticotropin-releasing hormone (CRH) [for review: (11)], a neuropeptide initially discovered in mammals for its role in the control of pituitary corticotropin and stress axis [for reviews: $(12,13)]$.

$\mathrm{TSH}$, like gonadotropins, $\mathrm{LH}$, and $\mathrm{FSH}$, is a pituitary glycoprotein composed of two subunits, the alpha subunit (glycoprotein hormone alpha subunit, gpa), in common with gonadotropins, and a specific beta subunit $(t s h \beta)$, which confers the hormone specificity [for review: (14)]. Due to teleost-specific whole genome duplication [TSWGD; also referred to as "3R," for "third round of whole genome duplication" (15)], teleosts possess two $t \operatorname{sh} \beta$ paralogs, $\operatorname{sh} \beta a$ and $t \operatorname{sh} \beta b$ (16).
Our recent studies in Atlantic salmon, Salmo salar, revealed a remarkable functional divergence of the duplicated $t \operatorname{sh} \beta$ paralogs, with a striking peak of pituitary $\operatorname{tsh} \beta b$ transcripts at the time of smoltification, in early April, concomitantly with the change in rheotaxism and initiation of downstream migration, whereas no change was observed for $t$ sh $\beta a$. While previous studies by many authors in salmonids had only concerned the "classical" tsh $\beta a$ paralog, the demonstration of another paralog and its expression peak at smoltification provided the first evidence for the involvement of TSH in smoltification metamorphosis (17).

Furthermore, as shown by in situ hybridization, the two Atlantic salmon $t s h \beta$ paralogs are expressed by two different cell populations in the pituitary: $t \operatorname{sh} \beta a$ cells are abundant and located in the anterior adenohypophysis, while tsh $\beta b$ cells are less numerous, well detected only at the time of smoltification, and located in the dorsal adenohypophysis near to the pituitary stalk (17). This differential localization and abundance of TSH cells in salmon could be compared to the situation in mammals and birds, which present a "classical" TSH cell population in the pituitary pars distalis (PD) and a less numerous TSH cell population in the pars tuberalis (PT) adjacent to the pituitary stalk [mammals (18-20); birds (21)]. In birds and mammals, PTTSH acts retrogradely on hypothalamic area and is involved in the brain regulation of seasonal life-traits, such as reproduction, migration and hibernation [for reviews: (22-24)]. A similar potential role in the seasonal regulation of smoltification could be hypothesized for the $t s h \beta b$ paralog in salmon (17). While in birds and mammals, both pituitary TSH cell populations express the same single $t \operatorname{sh} \beta$ gene, the two TSH cell populations in Atlantic salmon express distinct $t \operatorname{sh} \beta a$ and $t \operatorname{sh} \beta b$ paralogs. This differential localization of the two paralogs, together with their sequence divergence [33\% identity; $48 \%$ similarity; (17)] and their striking differential regulation at smoltification, illustrate a typical case of subfunctionalization (17).

The present study aims at investigating whether the expression of the two $t s h \beta a$ and $t s h \beta b$ paralogs are under differential central and peripheral controls. As for our previous investigations (17), this study was performed on Atlantic salmon from the Loire-Allier population, the last extant population from long-river in Western Europe, currently endangered, and under a conservation program at the Conservatoire National du Saumon Sauvage (CNSS). The regulation and timing of smoltification is an especially critical issue for this long-river population, as compared to short-river-ones, as smoltification occurs up to $900 \mathrm{~km}$ upstream, and smolts need to perform a long downstream migration and reach the estuary in a narrow window of favorable physiological and environmental conditions.

We used primary cultures of Atlantic salmon pituitary cells to study the direct pituitary control of the expression of both $t \operatorname{sh} \beta$ genes. While in birds and mammals, the same $t \operatorname{sh} \beta$ gene is expressed in both PD and PT cells, here we take advantage of the expression of distinct paralogs, $t s h \beta a$ and $t s h \beta b$, by the two TSH cell populations in salmon, which enables us to follow their differential expression in whole mixed pituitary cell cultures. We tested the effects of central neurohormones, known to be 
involved in TSH regulation in vertebrates $(\mathrm{TRH}, \mathrm{CRH}$, and somatostatin, SRIH) as well as peripheral hormones reported to increase before and/or during smoltification [thyroid hormones, insulin-like growth factor (IGF1), and cortisol] [for reviews: $(6,25)]$. For comparison and validation, we also followed the regulation of the expression of growth hormone, $g h$, which may share some common regulatory factors with TSH in vertebrates, and which is involved in the regulation of osmoregulatory changes at smoltification in salmonids [for review: (26)].

\section{MATERIAL AND METHODS}

\section{Animals}

Atlantic salmon (Salmo salar) from the Loire-Allier population raised indoor under natural water, temperature, and photoperiod conditions, at the Conservatoire National du Saumon Sauvage (CNSS), Chanteuges, France (Agreement N ${ }^{\circ}$ B43 056 005; according to the ARRETE $N^{\circ}$ DDCSPP/CS/2016/40), were used. They were anesthetized with an overdose of ms222 $(0.4 \mathrm{ml} / \mathrm{L}$; Sigma-Aldrich, St. Louis, MI, USA) and killed by decapitation in accordance with guidelines and regulations according to the protocol approved by Cuvier Ethic Committee, France. For each cell culture, pituitaries from 40 to 100 juvenile salmon were collected in cell culture medium at CNSS, and immediately transferred on ice to MNHN, Paris, where cell dispersion and cultures were performed. In order to be able to detect $t \operatorname{sh} \beta b$ in pituitary cell cultures, salmon pituitaries were collected at different times in April (years 2015 and 2018) during the peak of its expression (17). For $t \operatorname{sh} \beta a$ expression data, some additional experiments have been performed from January to April (years 2015, 2016, and 2018) with similar results as in April.

\section{Hormones}

Thyroid hormones and cortisol were purchased from SigmaAldrich (Saint-Quentin Fallavier, France; triiodothyronine, T3, catalog number: T2752; thyroxine, T4, catalog number: T2501; cortisol, F, catalog number: H4001), and used at similar doses as in previous in vitro studies in the eel $(27,28)$, covering circulating ranges.

Bovine corticotropin-releasing hormone $(\mathrm{CRH})$, which was shown to be effective on primary culture of pituitary cells from other teleost species [eel: (29); turbot: (30)], was purchased from Sigma-Aldrich (catalog number: C2671), and used at similar doses as in previous studies.

Thyrotropin-releasing hormone (TRH; catalog number: P1319) and somatostatin (SRIH; catalog number: S1763), fully conserved in vertebrates, were purchased from Sigma-Aldrich, and used at similar doses as in previous in vitro studies in other teleost species [eel: $(29,31)$; turbot: $(30)$ ].

Recombinant human insulin-like growth factor 1 (IGF1), which was shown to be effective on primary culture of pituitary cells from other teleost species [eel: (32); turbot: (33)], was purchased from R and D Systems (Lille, France; catalog number: 291-G1), and used at similar doses as in previous studies.
As in our previous studies, T3 and T4 were dissolved in $\mathrm{NaOH} 1 \mathrm{~N}$, cortisol in ethanol, $\mathrm{CRH}$, TRH and SRIH in sterile water and IGF1 in sterile PBS to obtain stock solutions $\left(10^{-3} \mathrm{M}\right)$, which were stored at $-20^{\circ} \mathrm{C}$.

\section{Primary Culture of Salmon Pituitary Cells Dispersion and Culture}

Dispersion and primary culture of pituitary cells were performed using an enzymatic and mechanical method adapted from [eel (34); salmon (35)]. Briefly, 40 to 100 pituitaries were incubated at $25^{\circ} \mathrm{C}$ in a solution of $0.8 \mathrm{mg}$ porcine type II trypsin (SigmaAldrich)/ml dispersion buffer (DB: Dulbecco's saline phosphate buffer without $\mathrm{Ca}^{2+}$ and $\mathrm{Mg}^{2+}$, with $100 \mathrm{U} / \mathrm{ml}$ penicillin, $100 \mu \mathrm{g} /$ $\mathrm{ml}$ streptomycin, and $250 \mathrm{ng} / \mathrm{ml}$ fungizone; Gibco, Thermo Fisher Scientific, Villebon-sur-Yvette, France). After $30 \mathrm{~min}$, the trypsin solution was replaced by a solution of $1 \mu \mathrm{g}$ DNase (Sigma-Aldrich) and $1 \mathrm{mg}$ soya bean trypsin inhibitor (SigmaAldrich)/ml DB for $10 \mathrm{~min}$. Pituitary slices were then washed with DB (Gibco) and mechanically dispersed in DB by repeated passages through a plastic transfer pipette (Falcon, Thermo Fisher Scientific). Cell suspensions were filtered through nylon mesh (30 $\mu \mathrm{m}$ pore size), harvested by centrifugation at $200 \mathrm{~g}$ for $10 \mathrm{~min}$, resuspended in $\mathrm{DB}$, and counted with a Malassez cytometer. The number of viable cells was estimated by Trypan Blue coloration exclusion (Sigma-Aldrich) and was about $90 \%$. Cells were plated on 96-well plates $(\sim 60,000$ cells/well) precoated with a solution of $0.1 \mathrm{mg} / \mathrm{ml}$ poly-L-lysine (SigmaAldrich). Cultures were performed in serum-free culture medium (Medium 199 with Earle's salt and sodium bicarbonate buffer, $100 \mathrm{U} / \mathrm{ml}$ penicillin, $100 \mathrm{\mu g} / \mathrm{ml}$ streptomycin, and $250 \mathrm{ng} / \mathrm{ml}$ fungizone; Gibco) at $18^{\circ} \mathrm{C}$ under $3 \% \mathrm{CO}_{2}$ and saturated humidity in tissue culture incubator (Galaxy 170R, Eppendorf, France).

\section{In Vitro Treatments}

Treatments were started $24 \mathrm{~h}$ after the beginning of culture to allow cell attachment (Day 0). Replicates of five wells for control and each treated group were used. Stock solutions $\left(10^{-3} \mathrm{M}\right)$ were diluted in culture medium just before addition to the culture wells. Culture medium was changed and treatment added to the cells on Day 0, Day 3, and Day 7. Cultures were stopped on Day 10 , according to our previous protocol (36-38). The effects of treatments were tested in three to five independent experiments performed on different cell preparations from different batches of fish. Figures display the results of representative experiments.

\section{Cell RNA Extraction and cDNA Synthesis}

Total RNA was directly extracted from cells in culture wells using the Cell-to-cDNA II Kit (Ambion Inc. Austin, TX, USA) according to the manufacturer's recommendations. Cells were washed with PBS (Gibco) and lysed with Cell Lysis II Buffer (80 $\mu \mathrm{l} /$ well). The lysates were digested with RNase-free DNase I (Roche Ltd., Basel, Switzerland). Four $\mu$ l of RNA solution of each samples was then reverse transcribed with the SuperScript III First Strand cDNA Synthesis Kit (Invitrogen Cergy-Pontoise, France). The samples obtained were stored at $-20^{\circ} \mathrm{C}$ until qPCR. 


\section{Real-Time Quantitative PCR (qPCR)}

Gene specific primers were previously designed based on the nucleotide sequences of the Atlantic salmon thyrotropin- $\beta$ subunit paralog a and paralog $\mathrm{b}(\operatorname{sh} \beta a$ and $t \operatorname{sh} \beta b)$ and $\beta$-actin (17), the latter being used as reference gene (Table 1). For growth hormone, $g h$, as the two paralogs, $g h 1$ and $g h 2$, issued from salmonid-specific WGD (40) have highly similar sequences and were regulated in the same manner in our pilot experiments (as tested on pooled samples, data not shown), common $g h$ specific primers (Table 1) were designed for Atlantic salmon, using the Primer3 Software (Whitehead Institute/Massachusetts Institute of Technology, Boston, MA, USA). Forward and reverse primers were located in different exons to prevent amplification of genomic DNA. To optimize the assay, different annealing temperatures were tested according to the melting temperature (Tm) of primers. To check their specificity, amplification products were sequenced at GATC Biotech (Mulhouse, France).

Quantitative PCR assays were performed using the LightCycler ${ }^{\circledR}$ System (Roche) with SYBR Green I sequenceunspecific detection as previously described $(17,38)$. The qPCRs were prepared with $4 \mu \mathrm{l}$ of diluted cDNA template, $2 \mu \mathrm{l}$ of PCR grade water, $2 \mu \mathrm{l}$ of SYBR Green master mix, and $1 \mu \mathrm{l}$ of each forward and reverse primer (500 $\mathrm{nM}$ each at final concentration). The protocol was an initial step of polymerase activation for $10 \mathrm{~min}$ at $95^{\circ} \mathrm{C}$; then 41 cycles $(\beta$-actin, gh and $t \operatorname{sh} \beta a)$ of $10 \mathrm{~s}$ at $95^{\circ} \mathrm{C}$ for denaturing, $5 \mathrm{~s}$ at $60^{\circ} \mathrm{C}$ for annealing, $10 \mathrm{~s}$ at $72^{\circ} \mathrm{C}$ for primer extension, and a single final extension step of $5 \mathrm{~min}$ at $72^{\circ} \mathrm{C}$. For $t \operatorname{sh} \beta b$, the protocol was an initial step of polymerase activation for $10 \mathrm{~min}$ at $95^{\circ} \mathrm{C} ; 51$ cycles of $10 \mathrm{~s}$ at $95^{\circ} \mathrm{C}, 5 \mathrm{~s}$ at $62^{\circ} \mathrm{C}, 10 \mathrm{~s}$ at $72^{\circ} \mathrm{C}$, and a single final extension step of $5 \mathrm{~min}$ at $72^{\circ} \mathrm{C}$. Each program ended with a melting curve analysis by slowly increasing the temperature $\left(0.01^{\circ} \mathrm{C} / \mathrm{s}\right)$ up to $95^{\circ} \mathrm{C}$ with a continuous registration of changes in fluorescent emission intensity. Serial dilutions of cDNA pools of pituitary cells were used as a standard curve. One chosen dilution was also included in each run as a calibrator. Each qPCR run contained a non-template control (cDNA was substituted by water) for each primer pairs to confirm that reagents were not contaminated. The efficiency of all primers was tested, and the specificity of each reaction was assessed by melting curve analysis to ensure the presence of only one product. Each sample was analyzed in duplicate by qPCR. Normalization of data was performed using $\beta$-actin mRNA level and results expressed as arbitrary units, relatively to mean value of control group, considered as 1 .

TABLE 1 | Primer sequences used in GPCR amplifications.

\begin{tabular}{lll}
\hline Primers & \multicolumn{1}{c}{ 5'-3' sequence (bp) } & \\
\hline actin-F & CCAAAGCCAACAGGGAGAAG & Olsvik et al. (39) \\
actin-R & AGGGACAACACTGCCTGGAT & Fleming et al. (17) \\
tsh $\beta a-F$ & CTCCTTGCCTGCTCTTCAG & Fleming et al. (17) \\
$t s h \beta a-R$ & GGCCAGCTCCTTCATGTTAC & Fleming et al. (17) \\
$t s h \beta b-F$ & TTGCCGTCAACACCACCAT & Fleming et al. (17) \\
$t s h \beta b-R$ & GGGATGATAGACCAGGGAGTG & Fleming et al. (17) \\
$g h-\mathrm{F}$ & AGAAGCTCAGCGACCTCAAA & This study \\
$g h-\mathrm{R}$ & TGTCATCCAGGCTCAGTACG & This study
\end{tabular}

The table provides the sequences of forward $(F)$ and reverse $(R)$ primers used for qPCR of Atlantic salmon $\beta$-actin, tsh $\beta a$, tsh $\beta b$, and gh.

\section{Statistics}

Results are given as mean \pm SEM ( $n=5$ wells/treatment; 60,000 cells/well; cell culture from 40-100 pituitaries). Means were compared by one-way ANOVA Tukey's multiple comparison test using Instat (GraphPad Software Inc., San Diego, CA, USA). Differences are considered significant when $\mathrm{P}<0.05$.

\section{RESULTS}

\section{Detection of $t s h \beta a$ and $t s h \beta b$ Transcripts by qPCR in Pituitary Cell Cultures}

Transcript levels of $t$ sh $\beta a$ paralog could be well detected by qPCR in primary cultures of pituitary cells $(\sim 60,000$ cells/well) with similar expression levels in juvenile Atlantic parr or smolt, as tested in January (parr), April (smolt), and June (post-smolt) (data not shown). In contrast, transcript levels of $t \operatorname{sh} \beta b$ paralog in cell cultures were under qPCR detection limit in January and June and could be measured in April. In April, basal expression levels of $t s h \beta b$ were still lower than that of $t \operatorname{sh} \beta a$, as suggested by the difference in the average quantification cycle values (Cq) (20 Cq for $t \operatorname{sh} \beta a$ and $28 \mathrm{Cq}$ for $t \operatorname{sh} \beta b$, which would correspond to about 500-fold difference in abundance).

\section{Effects of Thyroid Hormones (T3 and T4)}

The effects of various concentrations of T3 and T4 (from $10^{-11}$ to $10^{-7} \mathrm{M}$ ) were tested (Figure 1). Both T4 and T3 dosedependently downregulated $t \operatorname{sh} \beta a$ mRNA levels (Figure 1A). Their effects were significant at $10^{-11} \mathrm{M}(10 \%$ inhibition as compared to controls, $\mathrm{P}<0.05$ for T3 and $18 \%$ inhibition, $\mathrm{P}<$ 0.001 for T4) and reached for both hormones more than $85 \%$ inhibition at $10^{-9} \mathrm{M}(\mathrm{P}<0.001)$ and more than $95 \%$ inhibition at $10^{-7} \mathrm{M}(\mathrm{P}<0.001)$.

T3 and T4 also dose-dependently decreased $t \operatorname{sh} \beta b$ mRNA levels, but with a lower inhibitory effect than on $t \operatorname{sh} \beta a$ (Figure 1B). For T3, the effect was significant at $10^{-9} \mathrm{M}$ (24\% inhibition, $\mathrm{P}<0.01$ ) and reached $34 \%$ inhibition at $10^{-7} \mathrm{M}$, as compared to controls. For T4, the effect was significant at $10^{-7} \mathrm{M}$ with $25 \%$ inhibition.

T3 and T4 dose-dependently inhibited gh expression (Figure 1C). For T3, the effect was significant at $10^{-9} \mathrm{M}(25 \%$ inhibition, $\mathrm{P}<0.01)$ and reached $42 \%$ inhibition at $10^{-7} \mathrm{M}(\mathrm{P}<0.001)$ as compared to controls. For T4, the effect was significant at $10^{-7} \mathrm{M}$ with $32 \%$ inhibition $(\mathrm{P}<0.001)$.

\section{Effects of Cortisol (F)}

The effects of various concentrations of $\mathrm{F}$ (from $10^{-11}$ to $10^{-7} \mathrm{M}$ ) were tested (Figure 2).

Low doses $\left(10^{-11}\right.$ and $\left.10^{-9} \mathrm{M}\right)$ of $\mathrm{F}$ were ineffective in regulating $t \operatorname{sh} \beta a$ mRNA levels, but $10^{-7} \mathrm{M}$ had a significant inhibitory effect $(44 \%$ inhibition; $\mathrm{P}<0.001$, as compared to controls) (Figure 2A).

Low doses $\left(10^{-11}\right.$ and $\left.10^{-9} \mathrm{M}\right)$ of $\mathrm{F}$ had no effect on $t \operatorname{sh} \beta b$ mRNA levels, while $10^{-7} \mathrm{M}$ was able to strongly reduce them (72\% inhibition; $\mathrm{P}<0.001)$ (Figure 2B). 
A $\operatorname{tsh} \beta a$

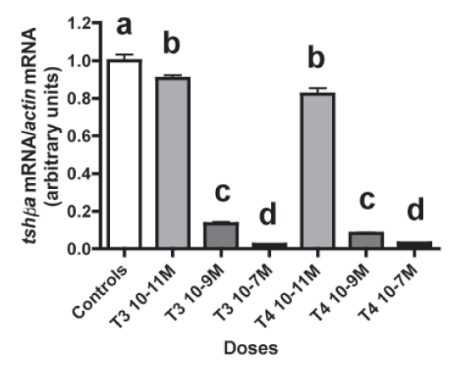

в $t \operatorname{sh} \beta b$

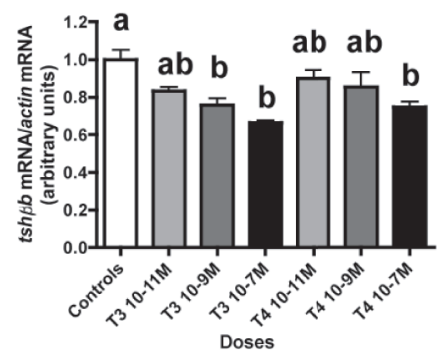

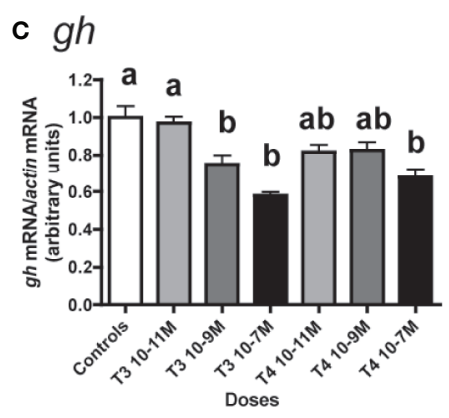

FIGURE 1 | Effects of thyroid hormones (T3 and T4) on tsh $\beta a$, $t$ sh $\beta b$, and gh transcript levels in primary cultures of Atlantic salmon pituitary cells. Pituitary cells from juvenile Atlantic salmons were treated with various concentrations of T3 or T4 for 10 days. The mRNA levels of tsh $\beta a$ (A), tsh $\beta b$ (B), and gh (C) were quantified by qPCR. Data were normalized against $\beta$-actin. The Figure displays the results from a representative experiment of three (tsh $\beta b)$ or five (tsh $\beta a$ and gh) independent cell culture experiments. Mean $\pm \mathrm{SEM} ; \mathrm{n}=5$ well replicates. Different letters indicate significant differences, ANOVA.

In contrast, none of the doses of $\mathrm{F}$ tested had any effect on $g h$ mRNA levels (Figure 2C).

\section{Effects of CRH and TRH Alone}

The effects of CRH and TRH $\left(10^{-8}\right.$ and $\left.10^{-6} \mathrm{M}\right)$ were tested (Figure 3). Both doses of CRH significantly increased the mRNA levels of $t \operatorname{sh} \beta a\left(\times 1.6\right.$ for $10^{-8} \mathrm{M} ; \times 1.7$ for $10^{-6} \mathrm{M}$; P $<0.001$ for both doses, as compared to controls) (Figure 3A). In contrast, TRH had no effect on $t s h \beta a$ mRNA levels at both doses (Figure 3A).

None of the two tested doses of CRH and TRH had any effect on $t$ sh $\beta b$ mRNA levels (Figure 3B).

Both doses of $\mathrm{CRH}$ increased the mRNA levels of $g h(\times 1.3$; $\mathrm{P}<$ 0.001 for both doses) (Figure 3C). TRH had no effect on $g h$ mRNA levels at both doses (Figure 3C).

\section{Effects of CRH and TRH in the Presence of T3}

The potential stimulatory effects of $\mathrm{CRH}$ or TRH on $t s h \beta$ paralogs were further investigated by testing the effects of $\mathrm{CRH}$ and TRH in combination with the inhibitory effect of T3 (Figure 4).

As observed above (Figure 3A), $10^{-6} \mathrm{M} \mathrm{CRH}$ alone stimulated tsh $\beta a$ mRNA levels $(\times 1.3 ; \mathrm{P}<0.001)$, while $10^{-6} \mathrm{M}$ TRH alone had no effect (Figure 4A). T3 at $10^{-8} \mathrm{M}$, as observed in Figure 1C, inhibited $t s h \beta a$ mRNA levels by more than $90 \%$ inhibition $(\mathrm{P}<0.001)$ (Figure 4A). In the presence of $10^{-8} \mathrm{M} \mathrm{T}$, the stimulation of $t \operatorname{sh} \beta a$ mRNA levels by $10^{-6} \mathrm{M} \mathrm{CRH}$ was greater $(\times 8.8 ; \mathrm{P}<0.001)$ than when tested alone, while $10^{-6} \mathrm{M}$ TRH had still no effect (Figure 4A).

Concerning the $t s h \beta b$ paralog, as observed above (Figure 3B), $10^{-6} \mathrm{M}$ of $\mathrm{CRH}$ or TRH alone had no effect on $t s h \beta b$ mRNA levels (Figure 4B). $10^{-8} \mathrm{M} \mathrm{T}$, as observed in Figure 1C, inhibited $t$ sh $\beta b$ mRNA levels (26\% inhibition) (Figure 4B). In the presence of T3, $10^{-6} \mathrm{M}$ of $\mathrm{CRH}$ and TRH had still no effect on tsh $\beta b$ mRNA levels (Figure 4B).

In order to further assess the stimulatory effect of $\mathrm{CRH}$ on $t \operatorname{sh} \beta a$ mRNA levels, different doses of $\mathrm{CRH}\left(10^{-10}, 10^{-8}\right.$, and $\left.10^{-6} \mathrm{M}\right)$ were tested in the presence of different doses of T3 $\left(10^{-10}, 10^{-9}\right.$, and $10^{-8}$ $\mathrm{M})$ (Figure 4C). T3 $\left(10^{-10} \mathrm{M}\right)$ inhibited $t$ sh $\beta a$ mRNA levels by $27 \%$ compared to controls $(\mathrm{P}<0.001)$. CRH dose-dependently stimulated $t$ sh $\beta a$ mRNA levels in the presence of $10^{-10} \mathrm{M} \mathrm{T}$ (up to $\times 1.8$ at $10^{-6} \mathrm{M} ; \mathrm{P}<0.001$, as compared to $10^{-10} \mathrm{M}$ T3 alone), which reached values higher than in non-treated controls $(\times 1.3$; $\mathrm{P}<$ 0.001; as compared to controls). T3 $\left(10^{-9} \mathrm{M}\right)$ inhibited tsh $\beta a$ mRNA levels by $84 \%$ compared to controls $(\mathrm{P}<0.001)$. CRH dosedependently stimulated $t \operatorname{sh} \beta a$ expression in the presence of $10^{-9}$ $\mathrm{M}$ T3 (up to $\times 3.2$ at $10^{-6} \mathrm{M} ; \mathrm{P}<0.001$, as compared to $10^{-9} \mathrm{M}$ T3 alone). T3 at $10^{-8} \mathrm{M}$ inhibited $t$ sh $\beta a$ mRNA levels by more than $90 \%$ compared to controls $(\mathrm{P}<0.001)$. CRH dose-dependently stimulated $t$ h $\beta a$ mRNA levels in the presence of $10^{-8} \mathrm{M} \mathrm{T3}$ (up to $\times 17$ at $10^{-6} \mathrm{M}$; $\mathrm{P}<0.001$, as compared to $10^{-8} \mathrm{M}$ T3 alone), but which still remained lower than in non-treated controls. Thus, the 
A $\operatorname{tsh} \beta a$

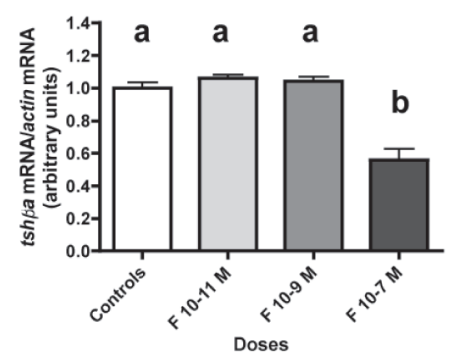

в $t \operatorname{sh} \beta b$

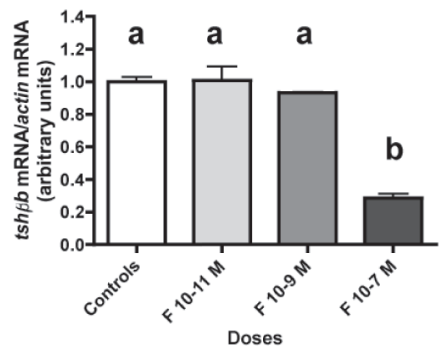

c $g h$

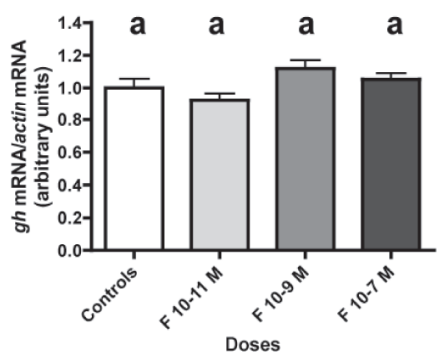

FIGURE 2 | Effects of cortisol (F) on the expression of $t s h \beta a$, tsh $\beta b$, and gh transcript levels in primary cultures of Atlantic salmon pituitary cells. Pituitary cells from juvenile Atlantic salmons were treated with various concentrations of F for 10 days. The mRNA levels of tsh $\beta a(\mathbf{A})$, tsh $\beta b$ (B), and gh (C) were quantified by qPCR. Data were normalized against $\beta$-actin. The Figure displays the results from a representative experiment of three independent cell culture experiments. Mean \pm SEM; $\mathrm{n}=5$ well replicates. Different letters indicate significant differences, ANOVA.

stimulatory effect of $\mathrm{CRH}$ on $t \operatorname{sh} \beta a$ was largely enhanced in the presence of high inhibitory doses of T3.

\section{Effects of CRH and TRH in the Presence of $\mathbf{F}$}

Similarly, the potential stimulatory effects of CRH $\left(10^{-6} \mathrm{M}\right)$ or TRH $\left(10^{-6} \mathrm{M}\right)$ were tested in combination with the inhibitory effect of $10^{-7} \mathrm{M} \mathrm{F}$ (Figure 5).

As observed above (Figures $\mathbf{3 A}$ and $\mathbf{4 A}$ ), $10^{-6} \mathrm{M} \mathrm{CRH}$ alone stimulated $t \operatorname{sh} \beta a$ mRNA levels $(\times 1.6 ; \mathrm{P}<0.001)$, while $10^{-6} \mathrm{M}$ $\mathrm{TRH}$ had no effect. $\mathrm{F}$ at $10^{-7} \mathrm{M}$, as observed in Figure 2A, moderately inhibited $t \operatorname{sh} \beta a$ mRNA levels ( $25 \%$ inhibition). In the presence of $\mathrm{F}$, the stimulation of $t \operatorname{sh} \beta a$ mRNA levels by $10^{-6} \mathrm{M}$ $\mathrm{CRH}$ was also found $\left(\times 1.8 ; \mathrm{P}<0.001\right.$, as compared to $10^{-7} \mathrm{M} \mathrm{F}$ alone), while $10^{-6} \mathrm{M}$ TRH had no effect (Figure 5A).

As observed above (Figures 3B and 4B), $10^{-6} \mathrm{M}$ of $\mathrm{CRH}$ or TRH alone had no effect on $t \operatorname{sh} \beta b$ mRNA levels. $\mathrm{F}$ at $10^{-7} \mathrm{M}$, as shown in Figure 2B, strongly inhibited $t s h \beta b$ mRNA levels (76\% inhibition). In the presence of F, $10^{-6} \mathrm{M}$ of $\mathrm{CRH}$ and TRH had still no effect on $t \operatorname{sh} \beta b$ mRNA levels (Figure 5B).

\section{Effects of SRIH}

The effect of SRIH $\left(10^{-8}\right.$ and $\left.10^{-6} \mathrm{M}\right)$ was tested (Figure 6). None of the two tested doses of SRIH had any effect on $t \operatorname{sh} \beta a$ and $b$ mRNA levels (Figures 6A, B). In contrast, $g h$ mRNA levels were strongly downregulated by SRIH (72\% inhibition at $10^{-8} \mathrm{M}$ and $74 \%$ inhibition at $10^{-6} \mathrm{M} ; \mathrm{P}<0.001$ for both doses, as compared to controls) (Figure 6C).

\section{Effects of IGF1}

The effects of various concentrations of IGF1 (from $10^{-12}$ to $10^{-7}$ $\mathrm{M})$ were tested (Figure 7). None of the six tested doses of IGF1 had any significant effect on $t s h \beta a$ mRNA levels (Figure 7A).

In contrast, IGF1 dose-dependently and strongly stimulated mRNA levels of the other paralog, $t \operatorname{sh} \beta b$ (Figure $7 \mathbf{B}$ ). The stimulatory effect of IGF1 was significant from $10^{-10} \mathrm{M}(\times 1.6$; $\mathrm{P}<0.05$, as compared to controls) and reached $\times 4.2$ at $10^{-7} \mathrm{M}$ ( $\mathrm{P}<0.001$, as compared to controls).

On the opposite, $g h$ mRNA levels were downregulated in a dose-dependent manner by IGF1 (Figure 7C). The inhibitory effect of IGF1 was significant at $10^{-10} \mathrm{M}$ (47\% inhibition) and reached a plateau with more than $85 \%$ inhibition at $10^{-9} \mathrm{M}(\mathrm{P}<$ 0.001 for all doses).

\section{DISCUSSION}

In the present study, we investigated the differential regulation of the duplicated $t \operatorname{sh} \beta a$ and $t \operatorname{sh} \beta b$ paralogs in the juvenile Atlantic 
A $t \operatorname{sh} \beta a$

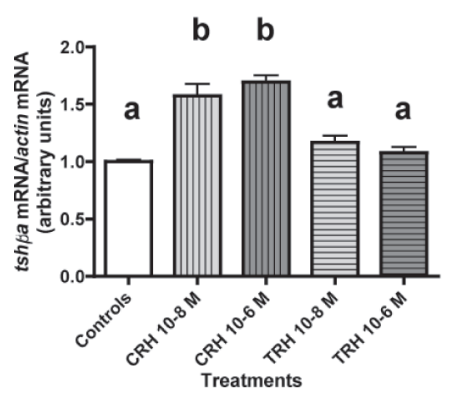

B $\operatorname{tsh} \beta b$

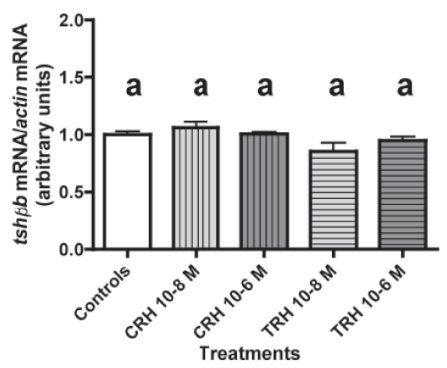

c $g h$

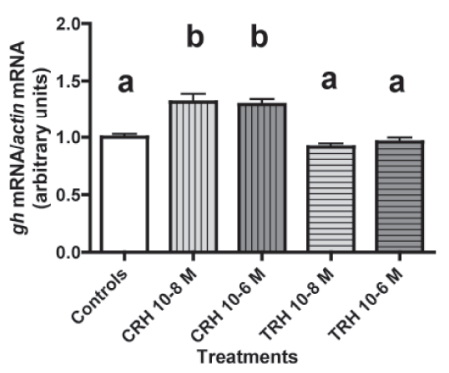

FIGURE 3 | Effects of $\mathrm{CRH}$ and TRH on $t s h \beta a, t s h \beta b$, and gh transcript levels in primary cultures of Atlantic salmon pituitary cells. Pituitary cells from juvenile Atlantic salmons were treated with $10^{-8}$ and $10^{-6} \mathrm{M}$ of $\mathrm{CRH}$ or TRH for 10 days. The mRNA levels of tsh $\beta a(\mathbf{A})$, tsh $\beta b$ (B), and gh (C) were quantified by qPCR. Data were normalized against $\beta$-actin. The Figure displays the results from a representative experiment of three independent cell culture experiments. Mean \pm SEM; $\mathrm{n}=5$ well replicates. Different letters indicate significant differences, ANOVA.

salmon by various central and peripheral neuroendocrine factors. We were especially interested in deciphering whether one of these factors could be potentially involved in the regulation of the striking peak of $t \operatorname{sh} \beta b$ transcript expression observed at the time of smoltification (17).

\section{Expression of $t s h \beta a$ and $t s h \beta b$ Paralogs in Primary Cultures of Atlantic Salmon Pituitary Cells}

We investigated the regulatory effects of neurohormones and hormones, as exerted directly at the pituitary level, by using primary cultures of Atlantic salmon pituitary cells. In mammals and birds, the same single $t \operatorname{sh} \beta$ gene is expressed by the two distinct pituitary PD- and PT-TSH cell populations, that requires to micro-dissect the $\mathrm{PT}$ and $\mathrm{PD}$ pituitary regions in order to investigate potential differential regulations in cell cultures. A series of investigations have been performed on primary cultures of ovine PT cells (41-44), but to our knowledge, these studies did not address the regulation of $t \operatorname{sh} \beta$ expression. Here, we took advantage of the $t \operatorname{sh} \beta a$ and $t \operatorname{sh} \beta b$ paralogs issued from the teleost whole genome duplication, each one being expressed in distinct anterior and dorsal pituitary TSH cell populations in Atlantic salmon. This makes it possible to evaluate their differential transcriptional regulation in the same experiments and the same conditions, in primary cultures of mixed pituitary cells.

Our culture system is based on a low number of pituitary cells per well ( 60,000 cells/well), as previously developed for the eel, Anguilla anguilla $(31,32)$, in order to limit the number offish being used, in agreement with the international recommendations for animal experimentation (Reduce, Refine, Replace), and especially relevant for species concerned by biodiversity conservation. In these conditions, both $t \operatorname{sh} \beta a$ and $t \operatorname{sh} \beta b$ transcripts could be measured by qPCR in primary cultures of pituitary cells of Atlantic salmon smolts, as performed in April at the time of smoltification climax. In contrast, $t \operatorname{sh} \beta b$ mRNA levels were under qPCR detection limit in pituitary cell cultures from parr (January) and post-smolts (June). This is in agreement with our previous studies on the annual expression profiles of $\operatorname{tsh} \beta a$ and tsh $\beta b$ paralogs in vivo, as measured by $\mathrm{qPCR}$ on whole pituitaries. In vivo, tsh $\beta a$ pituitary transcript levels remained unchanged from December to June, including the period of smoltification. In contrast, $t s h \beta b$ transcript levels were very low in juvenile salmon parr, in December and January, started increasing in FebruaryMarch to reach a peak in early April at the time of smoltificationrelated rheotaxism inversion, and dropped in May to reach back very low levels in June in post-smolts (17). Similarly, the lower 
A $t \operatorname{sh} \beta a$
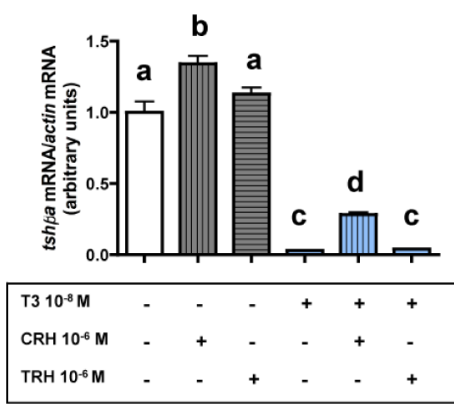

B $\operatorname{tsh} \beta b$
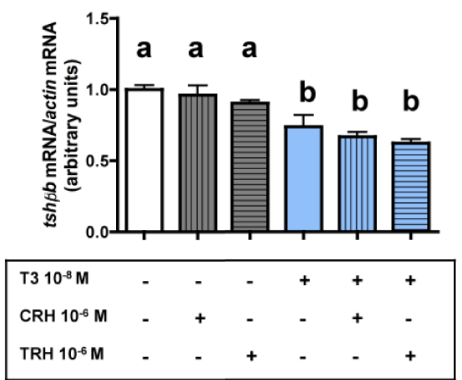

c $\operatorname{tsh} \beta a$

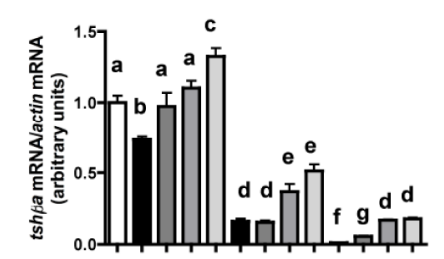

\begin{tabular}{|c|c|c|c|c|}
\hline T3 (M) & 0 & $10^{-10}$ & $10^{-9}$ & $10^{-8}$ \\
\hline CRH (M) & 0 & 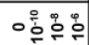 & 웋ㅎㅇ은웅 & ㅇํㅇ은웅웅 \\
\hline
\end{tabular}

FIGURE 4 | Effects of $\mathrm{CRH}$ and TRH on tsh $\beta$ a and $t s h \beta b$ transcript levels in the presence of T3 in primary cultures of Atlantic salmon pituitary cells. Pituitary cells from juvenile Atlantic salmons were treated for 10 days with $10^{-6} \mathrm{M}$ of $\mathrm{CRH}$ or $10^{-6} \mathrm{M} \mathrm{TRH}$ in the presence of $10^{-8} \mathrm{M}$ of T3, and $\mathrm{mRNA}$ levels of tsh $\beta$ a (A) and tsh $\beta \mathrm{b}$ (B) were quantified by qPCR. In (C), pituitary cells were treated for 10 days with various doses of $\mathrm{CRH}\left(10^{-10}, 10^{-8}\right.$, and $\left.10^{-6} \mathrm{M}\right)$ in the presence of various doses of T3 $\left(10^{-10}, 10^{-9}\right.$, and $\left.10^{-8} \mathrm{M}\right)$ and mRNA levels of $t s h \beta a$ were quantified by qPCR. The Figure displays the results from a representative experiment of three independent cell culture experiments. Mean \pm SEM; $n=5$ well replicates. Different letters indicate significant differences, ANOVA.

A $t \operatorname{sh} \beta a$

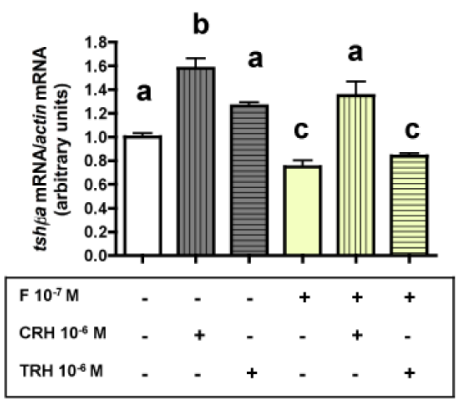

B $\operatorname{tsh} \beta b$

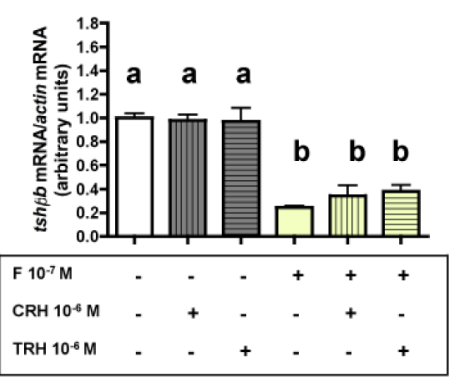

FIGURE 5 | Effects of $\mathrm{CRH}$ and TRH on tsh $\beta a$ and tsh $\beta b$ transcript levels in the presence of cortisol in primary cultures of Atlantic salmon pituitary cells. Pituitary cells from juvenile Atlantic salmons were treated for 10 days with $10^{-6} \mathrm{M}$ of $\mathrm{CRH}$ or $10^{-6} \mathrm{M} \mathrm{TRH}$ in the presence of $10^{-8} \mathrm{M}$ of cortisol (F) and mRNA levels of tsh $\beta a$ (A) and tsh $\beta b$ (B) were quantified by qPCR. Data were normalized against $\beta$-actin. The Figure displays the results from a representative experiment of three independent cell culture experiments. Mean \pm SEM; $n=5$ well replicates. Different letters indicate significant differences, ANOVA.

abundance of $t \operatorname{sh} \beta b$ than $t \operatorname{sh} \beta a$ basal transcript levels in cell cultures even in April, as suggested by the comparison of their respective qPCR quantification cycle values $(\mathrm{Cq})$, is in agreement with our previous results by $\mathrm{qPCR}$ on whole pituitaries and previous observation by in situ hybridization (17). This large difference in transcript abundance is in agreement with the hypothesis (17) of a local role and retrograde action toward the brain of the tsh $\beta b$ paralog, as for PT-TSH in amniotes, in contrast 
A $\operatorname{tsh} \beta a$

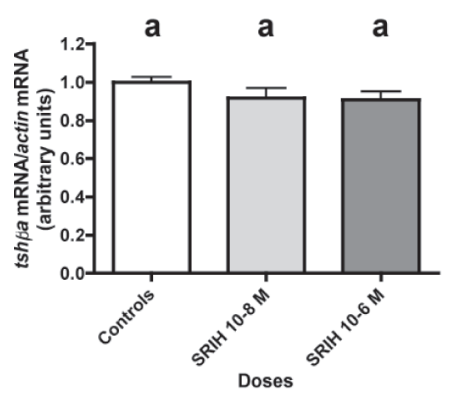

в $\operatorname{tsh} \beta b$

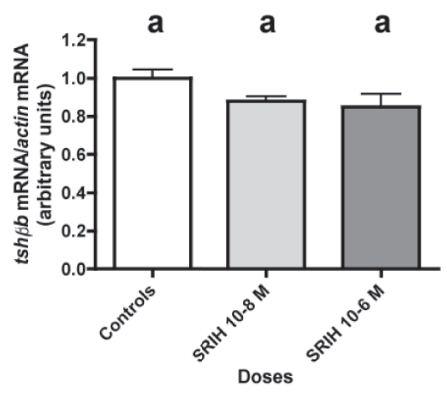

c $g h$

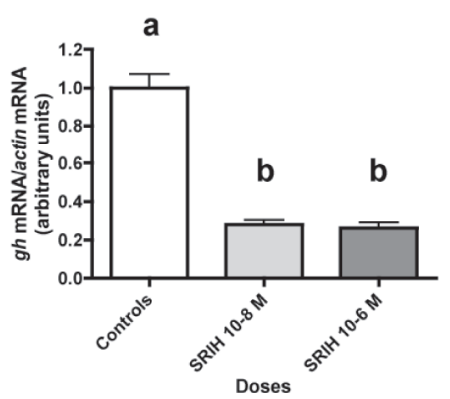

FIGURE 6 | Effects of SRIH on tsh $\beta a$, tsh $\beta b$, and gh transcript levels in primary cultures of Atlantic salmon pituitary cells. Pituitary cells from juvenile Atlantic salmons were treated with $10^{-8}$ and $10^{-6} \mathrm{M}$ of SRIH for 10 days. The mRNA levels of tsh $\beta a(\mathbf{A}), t s h \beta b$ (B), and gh (C) were quantified by qPCR. Data were normalized against $\beta$-actin. The Figure displays the results from a representative experiment of three independent cell culture experiments. Mean \pm SEM; $n=5$ well replicates. Different letters indicate significant differences, ANOVA.

to the endocrine role via the general blood circulation of the $t \operatorname{sh} \beta a$ paralog, as for PD-TSH in amniotes.

\section{Stronger Inhibition by Thyroid Hormones of $t s h \beta a$ Than $t s h \beta b$ Expression in Atlantic Salmon}

In salmonids, a rise of plasma T4 and/or T3 levels is observed at the time of smoltification [for reviews: $(6,45)$; Atlantic salmon, T4 and T3 (46); coho salmon Oncorhynchus kisutch, T4 (47, 48); coho, chinook salmon and steelhead trout, T4 and T3 (49); coho salmon, T4 and T3 $(50,51)$; masu salmon Oncorhynchus masou, T4 and T3 (52); masu salmon and amago salmon, Oncorhynchus rhodurus, T4 (53); masu salmon, T4 (54)]. As part of the thyrotropic axis, thyroid hormones (T3 and T4) are wellknown to exert a negative feedback on the pituitary, downregulating TSH production in mammals and other vertebrates [for reviews: $(9,10)]$.

In line with this negative feedback, our study showed that thyroid hormones dose-dependently inhibited the expression of the transcripts of both salmon $t \operatorname{sh} \beta$ paralogs. Remarkably, the inhibitory effect was much stronger on $t \operatorname{sh} \beta a$, with up to more than $95 \%$ inhibition, than on $t s h \beta b$, with a maximal inhibition of $25 \%$.
For comparison, we measured the impact of thyroid hormones on $g h$ transcript expression in Atlantic salmon pituitary cells. We also observed a moderate inhibitory effect of $\mathrm{T} 4$ and $\mathrm{T} 3$ on transcript expression, reaching a maximal inhibitory effect of $30 \%$. Our previous studies in the eel also showed an inhibitory regulation of GH synthesis and release by thyroid hormones, exerted directly at the pituitary level (28), and which may represent an ancestral and largely conserved crosstalk between somatotropic and thyrotropic axes in vertebrates [for review: (55)].

In teleosts, before the availability of bioassays for directly quantifying $\mathrm{TSH}$, one investigation mean was to look by histological methods at the activity of TSH cells. Baker thus observed that the addition of T4 to the culture medium of pituitary trout and eel culture prevents the hyperactivity of TSH cells in vitro [cytoplasmic degranulation (56); increase of uridine uptake (57)] suggesting that T4 has a direct negative effect on these cells. This cytological result was confirmed in guppy Poecilia reticulata $(58,59)$. In vivo experiments by Peter using implants of T4 in the pituitaries of goldfish and measuring radioactive iodine uptake by the thyroid gland also supported the existence of this negative feedback by T4 on the pituitary $(60,61)$. Later on, various in vivo studies in other teleosts confirmed these findings via direct measurements of $t s h \beta$ mRNA levels using 


\section{A $\operatorname{tsh} \beta a$}

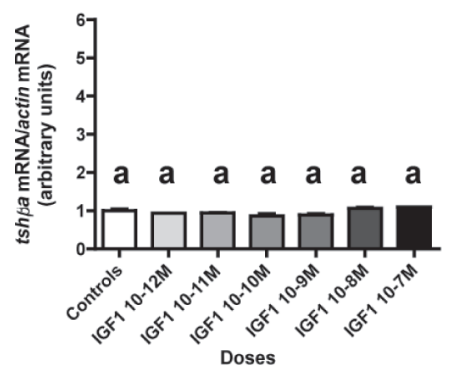

в $t \operatorname{sh} \beta b$

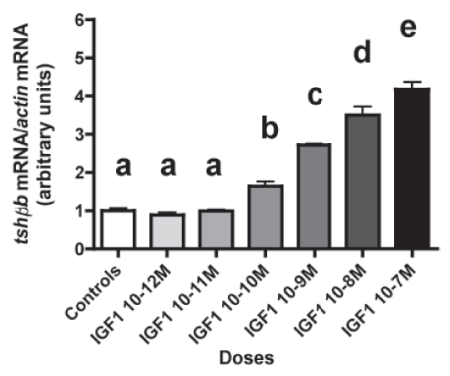

c $g h$

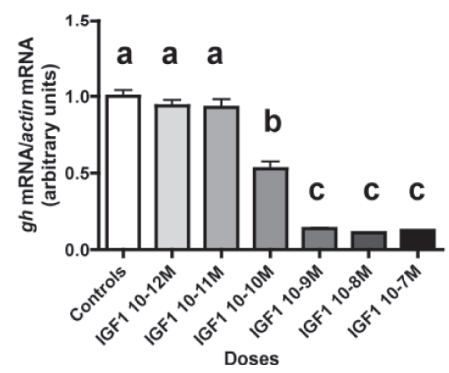

FIGURE 7 | Effects of IGF1 on tsh $\beta a$, tsh $\beta b$ and gh transcript levels in primary cultures of Atlantic salmon pituitary cells. Pituitary cells from juvenile Atlantic salmons were treated with various concentrations of IGF1 for 10 days. The mRNA levels of tsh $\beta a$ (A), tsh $\beta b$ (B), and gh (C) were quantified by qPCR. Data were normalized against $\beta$-actin. The Figure displays the results from a representative experiment of three independent cell culture experiments. Mean $\pm \mathrm{SEM} ; \mathrm{n}=5$ well replicates. Different letters indicate significant differences, ANOVA.

RNase protection assay [coho salmon (62)], Northern-blot [European eel (63); goldfish (64), turbot, Psetta maxima (65); red drum Sciaenops ocellatus (66)], or RT-PCR and qPCR [fathead minnow Pimephales promelas (67); bighead carp Aristichthys nobilis (68, 69); Japanese eel Anguilla japonica (70); red drum (71)]. Using in vitro primary culture of eel pituitary cells, Pradet-Balade and collaborators provided direct evidence that the negative feedback by $\mathrm{T} 3$ and $\mathrm{T} 4$ on $t \operatorname{sh} \beta$ mRNA levels was situated at the pituitary level (63).

All these former studies in teleosts, including salmonids, only concerned the "classical" $t \operatorname{sh} \beta a$ paralog. In contrast, in our study, we also investigated the second paralog, $t \operatorname{sh} \beta b$, and showed that both T3 and T4 inhibited the transcript expression of the second paralog, but to a much lesser extent than for the "classical" $t \operatorname{sh} \beta a$ paralog. We may suggest that the lower inhibitory effect of T3 and $\mathrm{T} 4$ on $t \operatorname{sh} \beta b$ thus might not prevent the peak of $t \operatorname{sh} \beta b$ transcript levels to happen during smoltification (17), despite an increase in plasma thyroid hormone concentrations at that time [Atlantic salmon, T4 and T3 (46)].

In the rat, Bockman and collaborators also reported a differential effect of thyroid hormones in vivo on the regulation of $t \operatorname{sh} \beta$ transcript levels in the PT (likely equivalent to salmon $t s h \beta b$ ) and in the PD (likely equivalent to salmon $t s h \beta a$ ) (72). T4 treatment did not affect the expression of $t \operatorname{sh} \beta$ in the PT, while it downregulated the expression of $t \operatorname{sh} \beta$ in the PD (72). The lack of effect of T4 on PT tsh $\beta$ transcription could be related by the authors to the lack of detection of thyroid hormone receptor TR $\beta$ mRNA in $\mathrm{PT}$, while the receptor is expressed in the PD (72). However, other in vivo studies indicated that $\mathrm{PT}$-TSH cells may be more sensitive to thyroid hormones during fetal development than in adulthood in rats. In fetal rats indeed, TSH-positive PT-specific cells react to changes in thyroid function similarly to PD thyrotropes: PT-TSH cell nuclei were enlarged in fetus from females treated with an antithyroid drug (PTU) and smaller in fetus from T4-treated females (73). In contrast, in adult rats, no ultrastructural alterations are observed after thyroidectomy (74) or treatment with PTU (75). As compared to mammals, thyroid hormone receptors have been duplicated through teleost and salmon specific whole genome duplications. Future studies may aim at determining which thyroid hormone receptor(s) are expressed by the two TSH pituitary cell types in Atlantic salmon and the regulation of their expression at the time of smoltification. This would also assess whether the actions of thyroid hormones are exerted directly or indirectly on each type of TSH cells. 


\section{Stronger Inhibition by Cortisol of tsh $\beta b$ Than tsh $\beta a$ Expression in Atlantic Salmon}

Cortisol, in most mammals and ray finned fish, and corticosterone, in most birds, amphibians, and reptiles, are the major glucocorticoids in vertebrates [for review: (76)]. In addition to its role in the control of metabolism and stress response in all vertebrates, cortisol is involved in osmoregulation in teleosts, and in particular in seawater adaptation of smolts in salmonids [for reviews: $(7,77)]$.

In our study, cortisol at the highest dose tested $\left(10^{-7} \mathrm{M}\right)$ was able to inhibit the mRNA levels of both $t \operatorname{sh} \beta$ paralogs, with a stronger effect on $t \operatorname{sh} \beta b$ (about $70 \%$ inhibition) than $t \operatorname{sh} \beta a$ (about $40 \%$ inhibition). To our knowledge, no study is available in teleosts concerning the effect of cortisol on TSH, even on the "classical" tsh $\beta a$ paralog. No effect was observed on gh transcript levels.

In human, it is known for a long time that glucocorticoid excess suppresses TSH secretion (78-80), while deficiency increases it $(78,81,82)$. In rodents, early in vivo studies also reported a suppressive effect of glucocorticoids on basal TSH release (8385). However, in vitro studies on rat pituitary cells in culture reported no changes in basal TSH levels after corticosterone treatment (86). In chicken, corticosterone inhibits in vivo, but not in vitro, sensitivity of thyrotropes to $\mathrm{CRH}$ at embryonic stage, suggesting an indirect mechanism of glucocorticoids on TSH in sauropsids (87).

In Atlantic salmon, plasma cortisol levels are low in winter and early spring (less than $10 \mathrm{ng} / \mathrm{ml}$ ) and peak in May up to 40 to $100 \mathrm{ng} / \mathrm{ml}(88,89)$, values largely compatible with the cortisol dose effective in our study. Same observation was made in coho salmon (90). The fact that cortisol strongly reduces $t s h \beta b$ mRNA levels in our study suggests that this hormone may potentially contribute to the termination of the $t \operatorname{sh} \beta b$ peak observed at the end of April and May (17).

\section{Stimulation by CRH of tsh $\beta$ a But Not tsh $\beta b$ Expression, and No Effect of TRH on Both Paralogs in Atlantic Salmon}

We compared the effects of $\mathrm{CRH}$ and $\mathrm{TRH}$, both main central regulators of thyrotropic axis in vertebrates, on Atlantic salmon $t \operatorname{sh} \beta \mathrm{a}$ and $\mathrm{b}$ paralog expression.

We showed a slight (about 1.5-fold increase), but significant, stimulatory effect of CRH on the transcript levels of $t \operatorname{sh} \beta a$, but not on those of $t \operatorname{sh} \beta b$. In the presence of T3 or cortisol, which downregulated the levels of both $t \operatorname{sh} \beta$ paralogs, $\mathrm{CRH}$ kept its stimulatory effect on $t \operatorname{sh} \beta a$ mRNA levels, but still had no effect on $t \operatorname{sh} \beta b$. Furthermore, the effect of CRH on $t s h \beta a$ mRNA levels was largely enhanced in the presence of high inhibitory doses of T3, reaching up more than 15 -fold increase (as compared to T3 alone), in the presence of $10^{-8} \mathrm{M}$ T3. In contrast, TRH has no effect on either $t s h \beta a$ nor $t s h \beta b$ in the absence or presence of inhibitors. These results demonstrated a stimulatory effect of CRH specifically on $t \operatorname{sh} \beta a$, but not $t \operatorname{sh} \beta b$, paralog expression.

For comparison, we also analyzed the effects of $\mathrm{CRH}$ and TRH on $g h$ transcript levels. $\mathrm{CRH}$, but not TRH, had a slight but significant stimulatory effect on $g h$ mRNA levels. Our previous studies reported a stimulatory effect of $\mathrm{CRH}$ on $\mathrm{GH}$ release in the European eel, which suggested a key role of CRH in the control of several neuroendocrine (corticotropic, somatotropic, and thyrotropic axes) (29).

In mammals, TRH was discovered for its stimulatory role on TSH secretion by the adenohypophysis (91). Concerning the PT, in vivo treatment in the rat showed a stimulatory effect of TRH on $\mathrm{PD}$ - $t \operatorname{sh} \beta$ transcript levels (likely equivalent to salmon $t \operatorname{sh} \beta a$ ), but no effect on PT-tsh $\beta$ (likely equivalent to salmon $t \operatorname{sh} \beta b$ ) (72). The authors were able to relate this differential regulation to the expression of TRH receptor transcripts in the PD but not in the PT. Future studies may aim at investigating the expression of $\mathrm{CRH}$ receptor(s) in salmon pituitary tsh $\beta a$ - and $t s h \beta b$-cells, taking into account that multiple $\mathrm{CRH}$ receptors are present in teleosts [for reviews: $(92,93)]$. This would also allow to decipher the mechanisms of enhanced effect of $\mathrm{CRH}$ on $t s h \beta a$ expression in the presence of T3: whether basal tsh $\beta a$ expression in cell culture is almost maximal and needs to be inhibited for revealing potential stimulatory actions, as shown for instance for $\mathrm{GH}$ production by pituitary cell cultures in turbot (30); or whether T3 inhibits $t \operatorname{sh} \beta a$ expression but also stimulates $\mathrm{CRH}$ receptor expression.

In teleosts, few studies have yet investigated the potential role of $\mathrm{CRH}$ on the thyrotropic axis. Two studies reported a stimulatory effect of $\mathrm{CRH}$ on thyrotropic axis, one in vivo on thyroid activity in goldfish (94) and one in vitro on TSH secretion by coho salmon pituitary cell culture (95). Another study reported no change of $t \operatorname{sh} \beta$ mRNA levels after $\mathrm{CRH}$ treatment in common carp (Cyprinus carpio) pituitary cell culture (96). Concerning $\mathrm{TRH}$, it became apparent that in non-mammalian vertebrates, notably in teleosts, TRH not always possesses a TSH-releasing role [for reviews: $(10,11)$ ]. The first studies reporting no effect of TRH on TSH release were performed in vivo and used indirect measurements. Wildmeister and Horster showed that administration of TRH did not induce exophthalmos in goldfish, while treatment with TSH did (97). In this species, treatment with TRH was indeed ineffective in affecting plasma T4 concentrations (98). In the African lungfish Protopterus ethiopicus, radioiodine uptake by the thyroid gland was not affected by TRH injection, but increased by TSH (99). However, other studies using the same kind of indirect measurements did show a stimulatory role of TRH [for review: (100)]. Bromage even described an inhibitory effect of $\mathrm{TRH}$ injection to guppies on thyroid and TSH cell activities (101). It is only later that in vitro experiments directly demonstrated species-specific differences in the role of TRH on TSH in teleosts. While TRH is able to increase $t \operatorname{sh} \beta$ mRNA levels in bighead carp $(68,69)$ and Japanese eel $(70)$, it is not the case in common carp $(96,102)$. In coho salmon, CRH stimulated TSH secretion, while TRH had no effect (95).

$\mathrm{CRH}$ ability to stimulate TSH secretion in anuran amphibians was demonstrated by in vitro (103) and in vivo studies (104106 ), and when comparison was made, a greater potency of CRH than TRH on TSH was observed [for reviews: $(1,11,107)]$. A stimulatory effect of $\mathrm{CRH}$ on TSH release was also found in chelonian sauropsids, as investigated in turtles $(108,109)$. In 
birds also, in vivo and in vitro studies reported a stimulatory effect of CRH on TSH $(87,110,111)$.

$\mathrm{CRH}$ neurogenesis has been shown to increase from parr to early-smolts in anadromous Atlantic salmon (112). In landlocked salmons receiving thyroxine to augment thyroid hormone plasma levels to those of anadromous fish, the rate of CRH neurogenesis is elevated to anadromous fish levels (112). $\mathrm{CRH}$ has been shown to stimulate locomotor activity in juvenile salmon (113). The present study shows that CRH exerts a specific stimulatory effect on $t \operatorname{sh} \beta a$ expression, but has no effect on $t \operatorname{sh} \beta b$. It thus demonstrates that neither $\mathrm{CRH}$ (nor TRH which has no effect on both tsh $\beta$ paralogs) would be involved in the triggering of the remarkable peak of pituitary $t s h \beta b$ paralog expression occurring at smoltification (17).

\section{No Effect of SRIH on tsh $\beta a$ and $t s h \beta b$ Expression in Atlantic Salmon}

Somatostatin (or somatotropin-releasing inhibitory hormone, $\mathrm{SRIH}$ ) was discovered for its inhibitory role on GH release in mammals (114-116), a role well conserved in vertebrates including teleosts [for review: (55)]. In addition to the inhibition of GH, SRIH may also exert an inhibitory effect on basal or TRH-induced TSH secretion in mammals [rat (115); human (117)].

In our study, using primary culture of salmon pituitary cells, SRIH showed its classical inhibitory action on GH, inducing more than $70 \%$ inhibition of $g h$ mRNA levels. In contrast, SRIH had no effect on both $t \operatorname{sh} \beta a$ and $t \operatorname{sh} \beta b$ mRNA levels.

In teleosts, early pioneer studies in goldfish addressed the potential inhibitory control of the thyrotropic axis. Pituitary transplantation (61), pituitary stalk sectioning, or hypothalamic lesioning (118) stimulated thyroid activity (measurement of conversion ratio, cell height, and radioiodine uptake). These studies provided indirect evidence for the existence of a brain TSH-inhibitory factor (TIF). Peter and McKeown (100) then investigated the potential role of SRIH as TIF in goldfish. They showed that injection of SRIH inhibited thyroid radioiodine uptake and suggested that SRIH action was mediated by inhibitory effect on TSH release. To our knowledge, no other studies investigated the potential role of SRIH on TSH in teleosts.

In birds, in vivo and in vitro studies showed an inhibitory effect of SRIH on TRH- or CRH-stimulation of TSH secretion $(111,119)$. This inhibition was likely mediated by SRIH receptors sstr2 and sstr5, which are expressed by the thyrotropes (120, 121). In amphibians, SRIH does not affect basal TSH secretion by bullfrog pituitary cells in culture (122).

\section{Specific Stimulation by IGF1 of $t s h \beta b$ Expression in Atlantic Salmon}

IGF1 is an endocrine growth factor mainly produced by the liver under the control of pituitary $\mathrm{GH}$, and acting on many target tissues to promote growth in mammals as well as in the other vertebrates [for review: (123)]. As a component of the somatotropic axis, IGF1 exerts a negative feedback on pituitary GH. IGF1, as well as GH itself, is also involved in the regulation of other functions such as reproduction, and osmoregulation in teleosts [for reviews: $(124,125)]$. IGF1 has also been proposed as one important internal signal in the cross-talks between growth, metabolism and triggering of puberty in mammals as well as in teleosts [eel (32); for reviews: $(124,126)]$.

In salmonids, IGF1 circulating levels have been shown to steadily increase from before to during smoltification [Atlantic salmon (127, 128); chinook salmon (129); masu salmon (130); for reviews: $(6,45)]$, and IGF1, together with GH and cortisol, has been proposed to regulate in smolt the adaptation of gills to osmoregulation in seawater [for reviews: $(131,132)$ ].

In the present study, we found a dose-dependent inhibitory effect of IGF1 on pituitary $g h$ transcripts (up to more than $85 \%$ inhibition), in agreement with the conservation of IGF1 negative feedback on the somatotropic axis throughout vertebrates.

Strikingly, our study revealed that IGF1 dose-dependently stimulates $t \operatorname{sh} \beta b$ transcript expression (up to 5-fold increase, according to the experiments). In contrast, no effect was observed on $t \operatorname{sh} \beta a$ mRNA levels, indicating that IGF1 stimulatory effect is specifically exerted on the $t s h \beta b$ paralog.

To our knowledge, our study is the first to report a direct pituitary regulatory role of IGF1 on $t \operatorname{sh} \beta$ mRNA levels in any vertebrate. IGF1 receptors are expressed in the ovine PT (133) and IGF1 has been shown to regulate mitogen-activated protein kinase in primary cultures of ovine PT cells (134). Three IGF1receptors paralogs have been identified in salmon (135). Future studies may investigate which of these receptors is expressed in the pituitary, and more specifically by cells expressing the $t \operatorname{sh} \beta b$ paralog, to decipher whether the IGF1 stimulatory effect is exerted directly on $t s h \beta b$ cells.

We recently demonstrated that $t \operatorname{sh} \beta b$ transcript levels peak during smoltification in Atlantic salmon in April concomitantly with rheotaxism inversion initiating downstream migration (17). Considering our present data on the specific stimulatory effect of IGF1 on this $t s h \beta b$ paralog, we can hypothesize that the increase of plasma IGF1 levels, which may start as early as February and lasts until May $(127,128)$, may be involved in the induction of smoltification-related $t s h \beta b$ expression.

In juvenile salmon, smoltification is preceded by a marked increase in body growth rate (130). As for puberty, where IGF1 is one of the internal cues linking body growth to activation of the gonadotropic axis, IGF1 may represent a key internal signal linking body growth to triggering of smoltification-related neuroendocrine changes in salmon.

In teleosts including salmons, as in other vertebrates, IGF1 is not only produced and released in the blood by the liver, as an endocrine factor, but also expressed locally in various tissues, such as gonad, gill, muscle, fat, heart, kidney, spleen, brain, and pituitary itself [for review: (136)], where it exerts local paracrine/autocrine actions. In tilapia, igf 1 transcripts are expressed in hypothalamic neurons with IGF1-immunoreactive axons projecting to the pituitary; igf1 transcripts are also expressed by some pituitary cells including some gonadotropes, and the number of igf1expressing gonadotropes increases at puberty as well as during seasonal reproduction (137). This led the authors to propose that pituitary IGF1 may act as paracrine/autocrine stimulator of gonadotropic cells during puberty and reproductive season 
[(137); for review: (124)]. We may suggest a similar role for IGF1 on $t s h \beta b$ thyrotropic expressing-cells during smoltification in salmon. Future studies will aim at investigating the localization and regulation of the igf 1 transcript in salmon brain and pituitary cells, during smoltification, to infer whether the stimulatory control on $t \operatorname{sh} \beta b$ expression may be exerted by locally produced IGF1.

IGF1 has been proposed to play a key role in the mediation of vertebrate life-traits [for reviews: $(138,139)$ ]. Our present findings suggest a role of IGF1 in the smoltification step during the life history of the long-river Loire-Allier salmon. This opens new research perspectives on the interactions between internal and environmental cues in the induction of smoltification in salmonids.

\section{CONCLUSION}

In conclusion, this study provides the first data on the neuroendocrine factors involved in the differential regulation of the expression of the two $t \operatorname{sh} \beta$ paralogs in teleosts. Future studies, including localization of neurohormone and hormone receptors on different cell types of the salmon pituitary, should aim at investigating whether these regulations are exerted directly on $t \operatorname{sh} \beta a$ or $t s h \beta b$-cells, or indirectly via interactions with other pituitary cells. Thyroid hormones had a stronger inhibitory effect on $t \operatorname{sh} \beta a$ than $t \operatorname{sh} \beta b$ in salmon, similar to the differential regulation by thyroid hormones of $t \operatorname{sh} \beta$ from PD versus from $\mathrm{PT}$ in the rat. $\mathrm{CRH}$ stimulated the expression of $t \operatorname{sh} \beta a$ with no effect on $t s h \beta b$, which can also be compared to the stimulatory effect of TRH on $t s h \beta$ from PD but not from PT, in the rat. This is the first report of IGF1 direct regulatory role on pituitary $t s h \beta$ in any vertebrate species. Strikingly, IGF1 specifically stimulated the expression of $t \operatorname{sh} \beta b$, allowing us to infer a potential key role of IFG1 in the triggering of the $t s h \beta b$ peak at smoltification and crosstalk between body growth and smoltification metamorphosis.

\section{REFERENCES}

1. Denver RJ. Neuroendocrinology of Amphibian Metamorphosis. Curr Top Dev Biol (2013) 103:195-227. doi: 10.1016/B978-0-12-385979-2.00007-1

2. Power DM, Einarsdóttir IE, Pittman K, Sweeney GE, Hildahl J, Campinho MA, et al. The molecular and endocrine basis of flatfish metamorphosis. Rev Fish Sci (2008) 16:93-109. doi: 10.1080/10641260802325377

3. Hoar W. Smolt transformation: evolution, behaviour, and physiology. J Fish Res Board Can (1976) 33:1234-52.

4. Boeuf G. Salmonid smolting: a pre-adaptation to the oceanic environment. In: J Rankin and F Jensen, editors. Fish Ecophysiology. London: Chapman and Hall Publ. (1993). p. 105-35.

5. McCormick SD. "Smolt Physiology and Endocrinology", in Euryhaline Fishes, Fish Physiology. SD McCormick, AP Farrell and CJ Brauner, Eds. Waltham, MA, USA: Academic Press, Elsevier (2012) 32:pp199-251. doi: 10.1016/B978-0-12-396951-4.00005-0.

6. Björnsson BT, Einarsdottir IE, Power D. Is salmon smoltification an example of vertebrate metamorphosis? Lessons learnt from work on flatfish larval development. Aquaculture (2012) 362-363:264-72. doi: 10.1016/j.aquaculture.2011.03.002

\section{DATA AVAILABILITY STATEMENT}

The raw data supporting the conclusions of this article will be made available by the authors, without undue reservation.

\section{ETHICS STATEMENT}

The animal study was reviewed and approved by Cuvier Ethic Commitee France.

\section{AUTHOR CONTRIBUTIONS}

SD, PM, KR: design of experiments. PM: supervision of fish husbandry. MF, GM, KR: cell culture. MF, GM, KR: qPCR. SD, KR: writing the manuscript. All authors: discussion of the results and reviewing the manuscript. All authors contributed to the article and approved the submitted version.

\section{FUNDING}

This work was supported by grants from the French National Research Agency SALTEMP-BIOADAPT ANR-12-ADAP-002101 and from the European community, Innovative Training Network, ITN IMPRESS MSCA-ITN-2014-ETN N 642893. MF was recipient of a PhD fellowship from ITN IMPRESS.

\section{ACKNOWLEDGMENTS}

We are grateful to Chanteuges CNSS team for fish husbandry and to Dr. AG Lafont (MNHN, BOREA) for designing primers for $g h$.

7. Rousseau K, Martin P, Boeuf G, Dufour S. Salmonid smoltification. In: S Dufour, K Rousseau and B Kapoor, editors. Metamorphosis in fish. Boca Raton: CRC Press (2012) p. 167-215.

8. Youson JH. First metamorphosis. In: Fish Physiology Volume XI, WS Hoar and DJ Randall Eds. Academic Press, San Diego (1988), 135-96.

9. Chin WW, Carr FE, Burnside J, Darling DS. Thyroid hormone regulation of thyrotropin gene expression. Recent Prog Horm Res (1993) 48:393-414. doi: 10.1016/b978-0-12-571148-7.50018-x

10. MacKenzie DS, Jones RA, Miller TC. Thyrotropin in teleost fish. Gen Comp Endocrinol (2009) 161:83-9. doi: 10.1016/j.ygcen.2008.12.010

11. De Groef B, Van Der Geyten S, Darras VM, Kühn ER. Role of corticotropinreleasing hormone as a thyrotropin-releasing factor in non-mammalian vertebrates. Gen Comp Endocrinol (2006) 146:62-8. doi: 10.1016/ j.ygcen.2005.10.014

12. Rivier C, Plotsky P. Mediation by Corticotropin Releasing Factor (CRF) of Adenohypophysial Hormone Secretion. Annu Rev Physiol (1986) 48:475-94. doi: 10.1146/annurev.physiol.48.1.475

13. Lovejoy DA, Balment RJ. Evolution and physiology of the corticotropinreleasing factor (CRF) family of neuropeptides in vertebrates. Gen Comp Endocrinol (1999) 115:1-22. doi: 10.1006/gcen.1999.7298 
14. Cahoreau C, Klett D, Combarnous Y. Structure-function relationships of glycoprotein hormones and their subunits' ancestors. Front Endocrinol (Lausanne) (2015) 6:26. doi: 10.3389/fendo.2015.00026

15. Meyer A, Van De Peer Y. From 2R to 3R: Evidence for a fish-specific genome duplication (FSGD). BioEssays (2005) 27:937-45. doi: 10.1002/bies.20293

16. Maugars G, Dufour S, Cohen-Tannoudji JL, Quérat B. Multiple thyrotropin b-subunit and thyrotropin receptor-related genes arose during vertebrate evolution. PLoS One (2014) 9:e111361. doi: 10.1371/journal.pone.0111361

17. Fleming MS, Maugars G, Lafont A-G, Rancon J, Fontaine R, NourizadehLillabadi R, et al. Functional divergence of thyrotropin beta-subunit paralogs gives new insights into salmon smoltification metamorphosis. Sci Rep (2019) 9:4561. doi: 10.1038/s41598-019-40019-5

18. Hanon EA, Lincoln GA, Fustin JM, Dardente H, Masson-Pévet M, Morgan PJ, et al. Ancestral TSH Mechanism Signals Summer in a Photoperiodic Mammal. Curr Biol (2008) 18:1147-52. doi: 10.1016/j.cub.2008.06.076

19. Ono H, Hoshino Y, Yasuo S, Watanabe M, Nakane Y, Murai A, et al. Involvement of thyrotropin in photoperiodic signal transduction in mice. Proc Natl Acad Sci U S A (2008) 105:18238-42. doi: 10.1073/ pnas.0808952105

20. Sáenz De Miera C, Monecke S, Bartzen-Sprauer J, Laran-Chich MP, Pévet P, Hazlerigg DG, et al. A circannual clock drives expression of genes central for seasonal reproduction. Curr Biol (2014) 24:1500-6. doi: 10.1016/ j.cub.2014.05.024

21. Nakao N, Ono H, Yamamura T, Anraku T, Takagi T, Higashi K, et al. Thyrotrophin in the pars tuberalis triggers photoperiodic response. Nature (2008) 452:317-22. doi: 10.1038/nature06738

22. Hazlerigg D, Loudon A. New Insights into Ancient Seasonal Life Timers. Curr Biol (2008) 18:795-804. doi: 10.1016/j.cub.2008.07.040

23. Dardente H, Hazlerigg DG, Ebling FJP. Thyroid hormone and seasonal rhythmicity. Front Endocrinol (Lausanne) (2014) 5:19. doi: 10.3389/ fendo.2014.00019

24. Dardente H, Wood S, Ebling F, Sáenz de Miera C. An integrative view of mammalian seasonal neuroendocrinology. J Neuroendocrinol (2019) 31: e12729. doi: 10.1111/jne.12729.

25. McCormick SD. Evolution of the hormonal control of animal performance: Insights from the seaward migration of salmon. Integr Comp Biol (2009) 49:408-22. doi: 10.1093/icb/icp044

26. Sakamoto T, McCormick SD, Hirano T. Osmoregulatory actions of growth hormone and its mode of action in salmonids: A review. Fish Physiol Biochem (1993) 11:155-64. doi: 10.1007/BF00004562

27. Huang Y-S, Rousseau K, Sbaihi M, Le Belle N, Schmitz M, Dufour S. Cortisol selectively stimulates pituitary gonadotropin $\beta$-subunit in a primitive teleost, Anguilla anguilla. Endocrinology (1999) 140:1228-35. doi: 10.1210/ endo.140.3.6598

28. Rousseau K, Le Belle N, Sbaihi M, Marchelidon J, Schmitz M, Dufour S. Evidence for a negative feedback in the control of eel growth hormone by thyroid hormones. J Endocrinol (2002) 175:605-13. doi: 10.1677/ joe. 0.1750605

29. Rousseau K, Le Belle N, Marchelidon J, Dufour S. Evidence that corticotropinreleasing hormone acts as a growth hormone-releasing factor in a primitive teleost, the European eel (Anguilla anguilla). J Neuroendocrinol (1999) 11:385-92. doi: 10.1046/j.1365-2826.1999.00334.x

30. Rousseau K, Le Belle N, Pichavant K, Marchelidon J, Chow BKC, Boeuf G, et al. Pituitary growth hormone secretion in the turbot, a phylogenetically recent teleost, is regulated by a species-specific pattern of neuropeptides. Neuroendocrinology (2001) 74:375-85. doi: 10.1159/000054704

31. Rousseau K, Huang Y-S, Le Belle N, Vidal B, Marchelidon J, Epelbaum J, et al. Long-term inhibitory effects of somatostatin and insulin-like growth factor 1 on growth hormone release by serum-free primary culture of pituitary cells from european eel (Anguilla anguilla). Neuroendocrinology (1998) 67:301-9. doi: 10.1159/000054327

32. Huang Y-S, Rousseau K, Le Belle N, Vidal B, Burzawa-Gérard E, Marchelidon J, et al. Insulin-like growth factor-I stimulates gonadotrophin production from eel pituitary cells: A possible metabolic signal for induction of puberty. J Endocrinol (1998) 159:43-52. doi: 10.1677/joe.0.1590043

33. Duval H, Rousseau K, Eliès G, Le Bail PY, Dufour S, Boeuf G, et al. Cloning, characterization, and comparative activity of turbot IGF-I and IGF-II. Gen Comp Endocrinol (2002) 126:269-78. doi: 10.1016/S0016-6480(02)00002-3
34. Montero M, Le Belle N, Vidal B, Dufour S. Primary cultures of dispersed pituitary cells from estradiol-pretreated female silver eels (Anguilla anguilla L.): Immunocytochemical characterization of gonadotropic cells and stimulation of gonadotropin release. Gen Comp Endocrinol (1996) 104:103-15. doi: 10.1006/gcen.1996.0146

35. Schmitz M. Differential effect of insulin-like growth factor I on in vitro gonadotropin subunits expression in Atlantic salmon. Fish Physiol Biochem (2003) 28:105-6. doi: 10.1023/B:FISH.0000030491.40805.96

36. Pasquier J, Lafont AG, Denis F, Lefranc B, Dubessy C, Moreno-Herrera A, et al. Eel Kisspeptins: Identification, functional activity, and inhibition on both pituitary LH and GnRH receptor expression. Front Endocrinol (Lausanne) (2018) 8:353. doi: 10.3389/fendo.2017.00353

37. Campo A, Lafont A-G, Lefranc B, Leprince J, Tostivint H, Kamech N, et al. Tachykinin-3 genes and peptides characterized in a basal teleost, the european eel: Evolutionary perspective and pituitary role. Front Endocrinol (Lausanne) (2018) 9:304. doi: 10.3389/fendo.2018.00304

38. Maugars G, Pasquier J, Atkinson C, Lafont A, Campo A, Kamech N, et al. Gonadotropin-inhibitory hormone in teleosts: New insights from a basal representative, the eel. Gen Comp Endocrinol (2020) 287:113350. doi: 10.1016/j.ygcen.2019.113350

39. Olsvik PA, Lie KK, Jordal AEO, Nilsen TO, Hordvik I. Evaluation of potential reference genes in real-time RT-PCR studies of Atlantic salmon. BMC Mol Biol (2005) 6:1-9. doi: 10.1186/1471-2199-6-21

40. Ocampo Daza D, Larhammar D. Evolution of the growth hormone, prolactin, prolactin 2 and somatolactin family. Gen Comp Endocrinol (2018) 264:94-112. doi: 10.1016/j.ygcen.2018.01.007

41. Morgan P, Lawson W, Davidson G, Howell H. Melatonin inhibits cyclic AMP production in cultured ovine pars tuberalis cells. J Mol Endocrinol (1989) 3:R5-8.

42. Morgan PJ, Lawson W, Davidson G. Interaction of Forskolin and Melatonin on Cyclic AMP Generation in Pars Tuberalis Cells of Ovine Pituitary. J Neuroendocrinol (1991) 3:497-501. doi: 10.1111/j.1365-2826.1991.tb00309.x

43. Hazlerigg DG, Morgan PJ, Lawson W, Hastings MH. Melatonin Inhibits the Activation of Cyclic AMP-Dependent Protein Kinase in Cultured Pars Tuberalis Cells from Ovine Pituitary. J Neuroendocrinol (1991) 3:597-603. doi: 10.1111/j.1365-2826.1991.tb00324.x

44. Barrett P, Morris MA, Moar KM, Mercer JG, Davidson JA, Findlay PA, et al. The differential regulation of CART gene expression in a pituitary cell line and primary cell cultures of ovine pars tuberalis cells. J Neuroendocrinol (2001) 13:347-52. doi: 10.1046/j.1365-2826.2001.00634.x

45. McCormick SD, Lerner DT, Monette MY, Nieves-Puigdoller K, Kelly JT, Björnsson BT. Taking it with you when you go: How perturbations to the freshwater environment, including temperature, dams, and contaminants, affect marine survival of salmon. Am Fish Soc Symp (2009) 69:195-214.

46. Boeuf G, Prunet P. Measurements of gill $(\mathrm{Na}+\mathrm{K}+)$-ATPase activity and plasma thyroid hormones during smoltification in Atlantic salmon (Salmo salar L.). Aquaculture (1985) 45:111-9. doi: 10.1016/0044-8486(85)90262-5

47. Dickhoff WW, Folmar LC, Gorbman A. Changes in plasma thyroxine during smoltification of coho salmon, Oncorhynchus kisutch. Gen Comp Endocrinol (1978) 36:229-32. doi: 10.1016/0016-6480(78)90027-8

48. Richman NH, Tai de Diaz S, Nishioka RS, Prunet P, Bern HA. Osmoregulatory and endocrine relationships with chloride cell morphology and density during smoltification in coho salmon (Oncorhynchus kisutch). Aquaculture (1987) 60:265-85. doi: 10.1016/ 0044-8486(87)90293-6

49. Dickhoff WW, Folmar LC, Mighell JL, Mahnken CVW. Plasma thyroid hormones during smoltification of yearling and underyearling coho salmon and yearling chinook salmon and steelhead trout. Aquaculture (1982) 28:3948. doi: 10.1016/0044-8486(82)90006-0

50. Larsen DA, Swanson P, Dickhoff WW. The pituitary-thyroid axis during the parr-smolt transformation of Coho salmon, Oncorhynchus kisutch: Quantification of TSH $\beta$ mRNA, TSH, and thyroid hormones. Gen Comp Endocrinol (2011) 171:367-72. doi: 10.1016/j.ygcen.2011.03.003

51. Young G, Björnsson B, Prunet P, Lin R, Bern H. Smoltification and seawater adaptation in coho salmon (Oncorhynchus kisutch): plasma prolactin, growth hormone, thyroid hormones, and cortisol. Gen Comp Endocrinol (1989) 74:335-45.

52. Nishikawa T, Hirashima T, Suzuki S, Suzuki M. Changes in Circulating LThyroxine and L-Triiodothyronine of the masu salmon, Oncorhynchus 
masou accompaning the smoltification, Measured by Radioimmunoassay. Endocrinol Jpn (1979) 26:731-5. doi: 10.1507/endocrj1954.26.731

53. Yamauchi K, Koide N, Adachi S, Nagahama Y. Changes in seawater adaptability and blood thyroxine concentrations during smoltification of the masu salmon, Oncorhynchus masou, and the amago salmon, Oncorhynchus rhodurus. Aquaculture (1984) 42:247-56. doi: 10.1016/ 0044-8486(84)90105-4

54. Yamauchi K, Ban M, Kasahara N, Izumi T, Kojima H, Harako T. Physiological and behavioral changes occurring during smoltification in the masu salmon, Oncorhynchus masou. Aquaculture (1985) 45:227-35. doi: 10.1016/0044-8486(85)90272-8

55. Rousseau K, Dufour S. Comparative aspects of GH and metabolic regulation in lower vertebrates. Neuroendocrinology (2007) 86:165-74. doi: 10.1159/ 000101029

56. Baker BI. The response of teleost pituitary thyrotrophs to thyroxin in vitro a histological study. Gen Comp Endocrinol (1969) 12:427-37.

57. Baker BI. Uptake of Uridine by Teleost Thyrotrophs in Vitro. Gen Comp Endocrinol (1969) 12:322-5.

58. Sage M. Responses of pituitary cells of Poecilia to changes in growth induced by thryroxine and thiourea. Gen Comp Endocrinol (1967) 8:314-9. doi: 10.1016/0016-6480(67)90078-0

59. Sage M, Bromage R. Interactions of the TSH and thyroid cells and gonads in Poecilid fishes. Gen Comp Endocrinol (1970) 14:137-40.

60. Peter RE. Feedback effects of thyroxine on the hypothalamus and pituitary of goldfish, Carassius auratus. J Endocrinol (1971) 51:31-9. doi: 10.1677/ joe. 0.0510031

61. Peter R. Feedback Effects of Thyroxine in Goldfish Carassius auratus with an Autotransplanted Pituitary. Neuroendocrinology (1972) 17:273-81.

62. Larsen DA, Dickey JT, Dickhoff WW. Quantification of salmon $\alpha$ - and thyrotropin (TSH) $\beta$-subunit messenger RNA by an RNase protection assay: Regulation by thyroid hormones. Gen Comp Endocrinol (1997) 107:98-108. doi: 10.1006/gcen.1997.6900

63. Pradet-Balade B, Schmitz M, Salmon C, Dufour S, Quérat B. Downregulation of TSH subunit mRNA levels by thyroid hormones in the European eel. Gen Comp Endocrinol (1997) 108:191-8. doi: 10.1006/ gcen.1997.6960

64. Yoshiura Y, Sohn YC, Munakata A, Kobayashi M, Aida K. Molecular cloning of the cDNA encoding the $\beta$ subunit of thyrotropin and regulation of its gene expression by thyroid hormones in the goldfish, Carassius auratus. Fish Physiol Biochem (1999) 21:201-10. doi: 10.1023/A:1007884527397

65. Pradet-Balade B, Burel C, Dufour S, Boujard T, Kaushik SJ, Boeuf G. Thyroid hormones down-regulate thyrotropin beta mRNA level in vivo in the turbot (Psetta maxima). Fish Physiol Biochem (1999) 20:193-9.

66. Cohn WB, Jones RA, Valverde RA, Leiner KA, MacKenzie DS. Molecular cloning and regulation of mRNA expression of the thyrotropin $\beta$ and glycoprotein hormone $\alpha$ subunits in red drum, Sciaenops ocellatus. Fish Physiol Biochem (2010) 36:1277-90. doi: 10.1007/s10695-010-9408-5

67. Lema SC, Dickey JT, Schultz IR, Swanson P. Thyroid hormone regulation of mRNAs encoding thyrotropin $\beta$-subunit, glycoprotein $\alpha$-subunit, and thyroid hormone receptors $\alpha$ and $\beta$ in brain, pituitary gland, liver, and gonads of an adult teleost, Pimephales promelas. J Endocrinol (2009) 202:4354. doi: 10.1677/JOE-08-0472

68. Chatterjee A, Hsieh YL, Yu JYL. Molecular cloning of cDNA encoding thyroid stimulating hormone $\beta$ subunit of bighead carp Aristichthys nobilis and regulation of its gene expression. Mol Cell Endocrinol (2001) 174:1-9. doi: 10.1016/S0303-7207(01)00392-6

69. Chowdhury I, Chien JT, Chatterjee A, Yu JYL. In vitro effects of mammalian leptin, neuropeptide-Y, $\beta$-endorphin and galanin on transcript levels of thyrotropin $\beta$ and common $\alpha$ subunit mRNAs in the pituitary of bighead carp (aristichthys nobilis). Comp Biochem Physiol - B Biochem Mol Biol (2004) 139:87-98. doi: 10.1016/j.cbpc.2004.06.007

70. Han YS, Liao IC, Tzeng WN, Yu JYL. Cloning of the cDNA for thyroid stimulating hormone $\beta$ subunit and changes in activity of the pituitary Thyroid axis during silvering of the Japanese eel, Anguilla japonica. J Mol Endocrinol (2004) 32:179-94. doi: 10.1677/jme.0.0320179

71. Jones RA, Cohn WB, Wilkes AA, MacKenzie DS. Negative feedback regulation of thyrotropin subunits and pituitary deiodinases in red drum,
Sciaenops ocellatus. Gen Comp Endocrinol (2017) 240:19-26. doi: 10.1016/ j.ygcen.2016.09.003

72. Bockmann J, Böckers T, Winter C, Wittkowski W, Winterhoff H, Deufel T, et al. Thyrotropin Expression in Hypophyseal Pars Tuberalis-specific cells is 3,5,3'-triiodothyronine, thyrotropin-releasing hormone, and Pit-1 independent. Endocrinology (1997) 138:1019-28.

73. Böckers TM, Sourgens H, Wittkowski W, Jekat A, Pera F. Changes in TSHimmunoreactivity in the pars tuberalis and pars distalis of the fetal rat hypophysis following maternal administration of propylthiouracil and thyroxine. Cell Tissue Res (1990) 260:403-8. doi: 10.1007/BF00318643

74. Oota Y, Kurosumi K. Electron microscopic studies on the pars tuberalis of the rat hypophysis. Arch Histol Jap (1966) 27:501-20.

75. Dellmann HD, Stoeckel ME, Hindelang-Gertner C, Porte A, Stutinsky F. A comparative ultrastructural study of the pars tuberalis of various mammals, the chicken and the newt. Cell Tissue Res (1974) 148:313-29. doi: 10.1007/ BF00224260

76. Aerts J. Quantification of a glucocorticoid profile in non-pooled samples is pivotal in stress research across vertebrates. Front Endocrinol (Lausanne) (2018) 9:635. doi: 10.3389/fendo.2018.00635

77. Takei Y, Hiroi J, Takahashi H, Sakamoto T. Diverse mechanisms for body fluid regulation in teleost fishes. Am J Physiol - Regul Integr Comp Physiol (2014) 307:R778-92. doi: 10.1152/ajpregu.00104.2014

78. Nicoloff JT, Fisher DA, Appleman MD. The role of glucocorticoids in the regulation of thyroid function in man. J Clin Invest (1970) 49:1922-9. doi: $10.1172 / J C I 106411$

79. Faglia G, Ferrari C, Beck-Peccoz P, Spada A, Travaglini P, Ambrosi B. Reduced plasma thyrotropin response to thyrotropin releasing hormone after dexamethasone administration in normal subjects. Horm Metab Res (1973) 5:289-92. doi: 10.1055/s-0028-1093930

80. Otsuki M, Dakoda M, Baba S. Influence of glucocorticoids on TRF-induced TSH secretion in man. J Clin Endocrinol Metab (1973) 36:95-102.

81. Topliss DJ, White EL, Stockigt JR. Significance of thyrotropin excess in untreated primary adrenal insufficiency. J Clin Endocrinol Metab (1980) 50:52-6. doi: 10.1210/jcem-50-1-52

82. Gonzalez JJ, Werk EE. Abnormal Thyrotropin and Prolactin Levels in Untreated Corticotropin Deficiency. Arch Intern Med (1985) 145:356-7. doi: 10.1001/archinte.1985.00360020200035

83. Wilber JF, Utiger RD. The Effect of Glucocorticoids on Thyrotropin Secretion. J Clin Invest (1969) 48:2096-103.

84. Marceau H, Delgado A, Macintosh-Hardt B, Fortier C. Metabolic clearance and secretion rates of TSH following adrenalectomy and corticosterone administration in the rat. Endocrinology (1972) 90:973-80. doi: 10.1210/ endo-90-4-973

85. Ranta T. Effect of dexamethasone on the secretion of thyrotropin in the rat: Dose and time relations. Endocrinology (1975) 96:1566-70. doi: 10.1210/ endo-96-6-1566

86. Pamenter RW, Hedge GA. Inhibition of thyrotropin secretion by physiological levels of corticosterone. Endocrinology (1980) 106:162-6. doi: 10.1210/endo-106-1-162

87. Geris KL, Laheye A, Berghman LR, Kühn ER, Darras VM. Adrenal inhibition of corticotropin-releasing hormone-induced thyrotropin release: A comparative study in pre- and posthatch chicks. J Exp Zool (1999) 284:776-82.

88. Langhorne P, Simpson TH. The interrelationship of cortisol, Gill $(\mathrm{Na}+\mathrm{K})$ ATPase, and homeostasis during the Parr-Smolt transformation of atlantic salmon (Salmo salar L.). Gen Comp Endocrinol (1986) 61:203-13. doi: 10.1016/0016-6480(86)90198-X

89. Sundell K, Jutfelt F, Ágústsson T, Olsen RE, Sandblom E, Hansen T, et al. Intestinal transport mechanisms and plasma cortisol levels during normal and out-of-season parr-smolt transformation of Atlantic salmon, Salmo salar. Aquaculture (2003) 222:265-85. doi: 10.1016/S0044-8486(03)00127-3

90. Barton BA, Schreck CB, Ewing RD, Hemmingsen AR, Patiño R. Changes in plasma cortisol during stress and smoltification in Coho Salmon, Oncorhynchus kisutch. Gen Comp Endocrinol (1985) 59:468-71. doi: 10.1016/0016-6480(85)90406-X

91. Guillemin R, Yamazaki E, Gard DA, Jutisz M, Sakiz E. In Vitro Secretion of Thyrotropin (Tsh): Stimulation By a Hypothalamic peptide (TRF). Endocrinology (1963) 73:564-72. doi: 10.1210/endo-73-5-564 
92. Lovejoy DA, Chang BSW, Lovejoy NR, del Castillo J. Molecular evolution of GPCRs: CRH/CRH receptors. J Mol Endocrinol (2014) 52:T43-60. doi: 10.1530/JME-13-0238

93. Cardoso JCR, Félix RC, Bergqvist CA, Larhammar D. New insights into the evolution of vertebrate CRH (corticotropin-releasing hormone) and invertebrate DH44 (diuretic hormone 44) receptors in metazoans. Gen Comp Endocrinol (2014) 209:162-70. doi: 10.1016/j.ygcen.2014.09.004

94. De Pedro N, Gancedo B, Alonso-Gomez AL, Delgado MJ, Alonso-Bedate M. CRF effect on thyroid function is not mediated by feeding behavior in goldfish. Pharmacol Biochem Behav (1995) 51:885-90. doi: 10.1016/00913057(95)00069-9

95. Larsen DA, Swanson P, Dickey JT, Rivier J, Dickhoff WW. In vitro thyrotropin-releasing activity of corticotropin-releasing hormone-family peptides in coho salmon, Oncorhynchus kisutch. Gen Comp Endocrinol (1998) 109:276-85. doi: 10.1006/gcen.1997.7031

96. Geven EJW, Flik G, Klaren PHM. Central and peripheral integration of interrenal and thyroid axes signals in common carp (Cyprinus carpio L.). J Endocrinol (2009) 200:117-23. doi: 10.1677/JOE-08-0410

97. Wildmeister W, Horster F. Die wirkung von synthetischem thyrotrophin releasing hormone auf die entwicklung eines experimentellen exophthalmus beim goldfisch. Acta Endocrinol (1971) 68:363-6.

98. Crim J, Dickhoff WW, Aubrey G. Comparative endocrinology of piscine hypothalamic hypophysiotropic peptides: Distribution and activity. Integr Comp Biol (1978) 18:411-24. doi: 10.1093/icb/18.3.411

99. Gorbman A, Mohamed H. Failure of Mammalian Function TRH to Stimulate in the Lungfish. Gen Comp Endocrinol (1973) 20:588-9.

100. Peter R, McKeown B. Hypothalamic control of prolactin and thyrotropin secretion in teleosts, with special reference to recent studies on the goldfish. Gen Comp Endocrinol (1975) 25:153-65. doi: 10.1016/0016-6480(75)90186-0

101. Bromage NR. The effects of mammalian thyrotropin-releasing hormone on the pituitary-thyroid axis of teleost fish. Gen Comp Endocrinol (1975) 25:292-7. doi: 10.1016/0016-6480(75)90118-5

102. Kagabu Y, Mishiba T, Okino T, Yanagisawa T. Effects of thyrotropinreleasing hormone and its metabolites, cyclo(His- Pro) and TRH-OH, on growth hormone and prolactin synthesis in primary cultured pituitary cells of the common carp, Cyprinus carpio. Gen Comp Endocrinol (1998) 111:395-403. doi: 10.1006/gcen.1998.7124

103. Denver RJ. Several hypothalamic peptides stimulate in vitro thyrotropin secretion by pituitaries of anuran amphibians. Gen Comp Endocrinol (1988) 72:383-93. doi: 10.1016/0016-6480(88)90160-8

104. Denver RJ. Acceleration of anuran amphibian metamorphosis by corticotropin-releasing hormone-like peptides. Gen Comp Endocrinol (1993) 91:38-51. doi: 10.1006/gcen.1993.1102

105. Denver RJ. Environmental stress as a developmental cue: Corticotropinreleasing hormone is a proximate mediator of adaptive phenotypic plasticity in amphibian metamorphosis. Horm Behav (1997) 31:169-79. doi: 10.1006/ hbeh.1997.1383

106. Denver RJ, Licht P. Neuropeptide stimulation of thyrotropin secretion in the larval bullfrog: Evidence for a common neuroregulator of thyroid and interrenal activity in metamorphosis. J Exp Zool (1989) 252:101-4. doi: $10.1002 /$ jez.1402520114

107. Kikuyama S, Okada R, Hasunuma I, Nakada T. Some aspects of the hypothalamic and pituitary development, metamorphosis, and reproductive behavior as studied in amphibians. Gen Comp Endocrinol (2019) 284:113212. doi: 10.1016/j.ygcen.2019.113212

108. Denver RJ, Licht P. Neuropeptides influencing in vitro pituitary hormone secretion in hatchling turtles. J Exp Zool (1989) 251:306-15. doi: 10.1002/ jez.1402510307

109. Denver RJ, Licht P. Several hypothalamic peptides stimulate thyrotropin and growth hormone secretion by adult turtle pituitary glands. Comp Biochem Physiol - Part A Physiol (1991) 100:603-6. doi: 10.1016/0300-9629(91) 90377-O

110. Geris KL, Kotanen SP, Berghman LR, Kühn ER, Darras VM. Evidence of a thyrotropin-releasing activity of ovine corticotropin- releasing factor in the domestic fowl (Gallus domesticus). Gen Comp Endocrinol (1996) 104:13946. doi: 10.1006/gcen.1996.0156

111. Geris KL, De Groef B, Kühn ER, Darras VM. In vitro study of corticotropinreleasing hormone-induced thyrotropin release: Ontogeny and inhibition by somatostatin. Gen Comp Endocrinol (2003) 132:272-7. doi: 10.1016/S00166480(03)00094-7

112. Ebbesson LOE, Nilsen TO, Helvik JV, Tronci V, Stefansson SO. Corticotropin-releasing factor neurogenesis during midlife development in salmon: Genetic, environmental and thyroid hormone regulation. J Neuroendocrinol (2011) 23:733-41. doi: 10.1111/j.1365-2826.2011.02164.x

113. Clements S, Schreck CB, Larsen DA, Dickhoff WW. Central administration of corticotropin releasing hormone stimulates locomotor activity in juvenile chinook salmon (Oncorhynchus tshawytscha). Gen Comp Endocrinol (2002) 125:319-27. doi: 10.1006/gcen.2001.7707

114. Brazeau P, Vale W, Burgus R, Ling N, Butcher M, Riviver J, et al. Hypothalamic polypeptide that inhibits the secretion of immunoreactive pituitary growth hormone. Sci (80- ) (1973) 179:77-9.

115. Vale W, Rivier C, Brazeau P, Guillemin R. Effects of somatostatin on the secretion of thyrotropin and prolactin. Endocrinology (1974) 95:968-77. doi: 10.1210/endo-95-4-968

116. Adams BA, Tello JA, Erchegyi J, Warby C, Hong DJ, Akinsanya KO, et al. Six novel gonadotropin-releasing hormones are encoded as triplets on each of two genes in the protochordate, Ciona intestinalis. Endocrinology (2003) 144:1907-19. doi: 10.1210/en.2002-0216

117. Siler TM, Yen SSC, Vale W, Guillemin R. Inhibition by somatostatin on the release of TSH induced in man by thyrotropin-releasing factor. J Clin Endocrinol Metab (1974) 38:742-5. doi: 10.1210/jcem-38-5-742

118. Peter R. Hypothalamic control of thyroid gland activity and gonadal activity in the goldfish, Carassius auratus. Gen Comp Endocrinol (1970) 14:334-56. doi: 10.1016/0016-6480(70)90062-6

119. Geris KL, De Groef B, Rohrer SP, Geelissen S, Kühn ER, Darras VM. Identification of somatostatin receptors controlling growth hormone and thyrotropin secretion in the chicken using receptor subtype-specific agonists. J Endocrinol (2003) 177:279-86. doi: 10.1677/joe.0.1770279

120. De Groef B, Geris KL, Manzano J, Bernal J, Millar RP, Abou-Samra AB, et al. Involvement of thyrotropin-releasing hormone receptor, somatostatin receptor subtype 2 and corticotropin-releasing hormone receptor type 1 in the control of chicken thyrotropin secretion. Mol Cell Endocrinol (2003) 203:33-9. doi: 10.1016/S0303-7207(03)00120-5

121. De Groef B, Grommen SVH, Darras VM. Feedback control of thyrotropin secretion in the chicken: Thyroid hormones increase the expression of hypophyseal somatostatin receptor types 2 and 5. Gen Comp Endocrinol (2007) 152:178-82. doi: 10.1016/j.ygcen.2007.01.036

122. Okada R, Yamamoto K, Ito Y, Chartrel N, Leprince J, Fournter A, et al. Effects of pituitary adenylate cyclase-activating polypeptide, vasoactive intestinal polypeptide, and somatostatin on the release of thyrotropin from the bullfrog pituitary. Ann N Y Acad Sci (2006) 1070:474-80. doi: 10.1196/ annals.1317.064

123. Beckman BR. Perspectives on concordant and discordant relations between insulin-like growth factor 1 (IGF1) and growth in fishes. Gen Comp Endocrinol (2011) 170:233-52. doi: 10.1016/j.ygcen.2010.08.009

124. Reinecke M. Insulin-like Growth Factors and Fish Reproduction. Biol Reprod (2010) 82:656-61. doi: 10.1095/biolreprod.109.080093

125. Reinecke M, Björnsson BT, Dickhoff WW, McCormick SD, Navarro I, Power $\mathrm{DM}$, et al. Growth hormone and insulin-like growth factors in fish: Where we are and where to go. Gen Comp Endocrinol (2005) 142:20-4. doi: 10.1016/ j.ygcen.2005.01.016

126. Taranger GL, Carrillo M, Schulz RW, Fontaine P, Zanuy S, Felip A, et al. Control of puberty in farmed fish. Gen Comp Endocrinol (2010) 165:483515. doi: 10.1016/j.ygcen.2009.05.004

127. Ágústsson T, Sundell K, Sakamoto T, Johansson V, Ando M, Björnsson BT. Growth hormone endocrinology of Atlantic salmon (Salmo salar): Pituitary gene expression, hormone storage, secretion and plasma levels during parr-smolt transformation. J Endocrinol (2001) 170:227-34. doi: 10.1677/joe.0.1700227

128. McCormick SD, Shrimpton JM, Moriyama S, Björnsson BT. Effects of an advanced temperature cycle on smolt development and endocrinology indicate that temperature is not a zeitgeber for smolting in Atlantic salmon. J Exp Biol (2002) 205:3553-60.

129. Beckman BR, Larsen DA, Moriyama S, Lee-Pawlak B, Dickhoff WW. Insulinlike growth factor-I and environmental modulation of growth during smoltification of spring chinook salmon (Oncorhynchus tshawytscha). Gen Comp Endocrinol (1998) 109:325-35. doi: 10.1006/gcen.1997.7036 
130. Shimomura T, Nakajima T, Horikoshi M, Iijima A, Urabe H, Mizuno S, et al. Relationships between gill $\mathrm{Na}+, \mathrm{K}+$-ATPase activity and endocrine and local insulin-like growth factor-I levels during smoltification of masu salmon (Oncorhynchus masou). Gen Comp Endocrinol (2012) 178:427-35. doi: 10.1016/j.ygcen.2012.06.011

131. McCormick SD. Effects of growth hormone and insulin-like growth factor I on salinity tolerance and gill $\mathrm{Na}+, \mathrm{K}+$-ATPase in Atlantic salmon (Salmo salar): Interaction with cortisol. Gen Comp Endocrinol (1996) 101:3-11. doi: 10.1006/gcen.1996.0002

132. Dickhoff WW, Beckman BR, Larsen DA, Duan C, Moriyama S. The role of growth in endocrine regulation of salmon smoltification. Fish Physiol Biochem (1997) 17:231-6. doi: 10.1023/a:1007710308765

133. Williams LM, Kelly D, Hannah L -T, Morgan PJ. Localization of [125I]IGF-I Binding on the Ovine Pars Tuberalis. J Neuroendocrinol (1995) 7:931-8. doi: 10.1111/j.1365-2826.1995.tb00738.x

134. Hazlerigg D, Thompson M, Hastings M, Morgan P. Regulation of mitogenactivated protein kinase in the pars tuberalis of the ovine pituitary: interactions between melatonin, insulin-like growth factor-1, and forskolin. Endocrinology (1996) 137:210-8.

135. Alzaid A, Martin SAM, Macqueen DJ. The complete salmonid IGF-IR gene repertoire and its transcriptional response to disease. Sci Rep (2016) 6:1-10. doi: 10.1038/srep34806

136. Wood AW, Duan C, Bern HA. Insulin-like growth factor signaling in fish. Int Rev Cytol (2005) 243:215-85. doi: 10.1016/S0074-7696(05)43004-1
137. Moret O, Berishvili G, Shved N, Eppler E, Helena D, Baroiller JF, et al. Insulin-like growth factor i (IGF-I) in the hypothalamicpituitary-gonadal (HPG) axis during development of male and female tilapia, Oreochromis niloticus. Cybium (2008) 32:31-3. doi: 10.5167/uzh-31715

138. Dantzer B, Swanson EM. Mediation of vertebrate life histories via insulinlike growth factor-1. Biol Rev (2012) 87:414-29. doi: 10.1111/j.1469185X.2011.00204.x

139. Lodjak J, Verhulst S. Insulin-like growth factor 1 of wild vertebrates in a lifehistory context. Mol Cell Endocrinol (2020) 518:110978.

Conflict of Interest: The authors declare that the research was conducted in the absence of any commercial or financial relationships that could be construed as a potential conflict of interest.

The reviewer PGV declared a past co-authorship with one of the authors SD, to the handling editor.

Copyright (c) 2020 Fleming, Maugars, Martin, Dufour and Rousseau. This is an openaccess article distributed under the terms of the Creative Commons Attribution License (CC BY). The use, distribution or reproduction in other forums is permitted, provided the original author(s) and the copyright owner(s) are credited and that the original publication in this journal is cited, in accordance with accepted academic practice. No use, distribution or reproduction is permitted which does not comply with these terms. 